\title{
Review: How Forage Feeding Early in Life Influences the Growth Rate, Ruminal Environment, and the Establishment of Feeding Behavior in Pre-Weaned Calves
}

\author{
Jianxin Xiao ${ }^{1,+}$, Gibson Maswayi Alugongo ${ }^{1,+}{ }^{\oplus}$, Jinghui $\mathrm{Li}^{2}$, Yajing Wang ${ }^{1}$, Shengli $\mathrm{Li}^{1}$ and \\ Zhijun Cao ${ }^{3, *}$ \\ 1 State Key Laboratory of Animal Nutrition, Beijing Engineering Technology Research Center of Raw Milk \\ Quality and Safety Control, College of Animal Science and Technology, China Agricultural University, \\ Beijing 100193, China; dairyxiao@gmail.com (J.X.); maswayi@yahoo.com (G.M.A.); \\ yajingwang_cau@163.com (Y.W.); lisheng0677@163.com (S.L.) \\ 2 Department of Animal Science, University of California, Davis, CA 95616, USA; lgreyhui@hotmail.com \\ 3 State Key Laboratory of Animal Nutrition, College of Animal Science and Technology, China Agricultural \\ University, Beijing 100193, China \\ * Correspondence: caozhijun@cau.edu.cn; Tel.: +86-10-6273-3746 \\ + These authors contributed equally to this review.
}

Received: 29 November 2019; Accepted: 19 January 2020; Published: 22 January 2020

Simple Summary: Under natural grazing systems, calves are likely to consume forage in early life. However, forage inclusion in the diet of pre-weaned calves has long been a controversial issue due to it possibly being associated with negative calf performance. Recent published literature seems to confound previous research. This review aims to understand the factors that may influence forage inclusion in the ration of pre-weaned calves. We have explored research related to the effect of feeding forage on rumen and behavioral development to better understand whether forage should be fed to the young calf. Based on the findings, it is concluded that a small amount of good quality forage is recommended for calves to improve their behavioral expression and rumen environment, which may further improve calf performance.

\begin{abstract}
The provision of forage to pre-weaned calves has been continuously researched and discussed by scientists, though results associated with calf growth and performance have remained inconsistent. Multiple factors, including forage type, intake level, physical form, and feeding method of both solid and liquid feed, can influence the outcomes of forage inclusion on calf performance. In the current review, we summarized published literature in order to get a comprehensive understanding of how early forage inclusion in diets affects calf growth performance, rumen fermentation, microbiota composition, and the development of feeding behavior. A small amount of good quality forage, such as alfalfa hay, supplemented in the diet, is likely to improve calf feed intake and growth rate. Provision of forage early in life may result in greater chewing (eating and ruminating) activity. Moreover, forage supplementation decreases non-nutritive oral and feed sorting behaviors, which can help to maintain rumen fluid $\mathrm{pH}$ and increase the number of cellulolytic bacteria in the rumen. This review argues that forage provision early in life has the potential to affect the rumen environment and the development of feeding behavior in dairy calves. Continued research is required to further understand the long-term effects of forage supplementation in pre-weaned calves, because animal-related factors, such as feed selection and sorting, early in life may persist until later in adult life.
\end{abstract}

Keywords: calves; forage; performance; rumen fermentation; behavior 


\section{Introduction}

As early as 1897, researchers began to evaluate hay feeding in young calves [1]. Since then, more calf related studies involving various aspects such as genetics, nutrition, health, and welfare have been completed [2]. Likewise, over the last hundred years, the use of forage in pre-weaned calves has remained one of the most key concerns in calf nutrition.

Before the 1950s, forage feeding was generally encouraged in pre-weaned calves, as it was believed to reduce abnormal behavior (e.g., eating bedding material) [3], lower diarrhea [4], and improve rumen development $[5,6]$. However, new research emerged challenging the fact that forage feeding could improve rumen development to the same degree as calf starter [7]. Volatile fatty acids (VFA) were considered to play a more critical role in stimulating rumen epithelial development rather than the physical form of diets [8]. Specifically, forage ration resulted in a higher proportion of acetate [9], which did not stimulate the growth of rumen papillae to the same extent as butyrate and propionate $[10,11]$. Concentrates, high in rapidly fermentable carbohydrates, produced more butyrate and propionate [12]. Therefore, higher proportions of concentrates could enhance the development of rumen papillae [13]. Furthermore, as fiber had lower digestibility than starch and sugar, many studies claimed that roughage increased gut fill because of low ruminal fermentation rate, thus curbing the consumption of starter feed which had higher energy density $[5,14,15]$. Therefore, some dairy farms provided calves with ad libitum access to concentrate feed, with no forage until after weaning [16]. More recently, in the 2000s and 2010s, more studies have investigated the effects of forage feeding in pre-weaned calves, yet results were inconsistent. Some of the studies reported a decrease [15,17], an increase [18-23], or no differences [24-27] in solid dry matter intake (DMI) and average daily gain (ADG) when forage was added in the calf diets. As the solid DMI and growth rate of the pre-weaned calves are important factors that drive rumen development [15] and subsequent milk production in the first lactation [28], it is vital to understand the factors that influence feed consumption and calf growth when forage is added to their diet.

On the other hand, over the last ten years, more research has explored the effects of forage inclusion in diets of young calves not only on calf performance and rumen morphological development but also on ruminal fermentation metabolites, bacterial composition, and feeding behavior [2], giving us a more comprehensive and better understanding of this topic. Therefore, the aims of this review are: (1) to discuss the factors that contribute to the inconsistent results in performance in calves with forage inclusion; (2) to summarize and evaluate the latest literature on the role of forage in rumen fermentation and the establishment of feeding behavior of calves.

\section{Factors that Affect Calf Performance with Forage Inclusion}

Generally, under natural grazing systems, adult dairy cows spend 7 to $13 \mathrm{~h}$ eating grass every day [29]. Young calves acquire nutrients from both milk and fresh grasses and begin to graze as early as week 2 of age [30,31]. The grazing time usually lasts for a short period, around $20 \mathrm{~min}$ at 10 days, which increases rapidly to $360 \mathrm{~min}$ at 100 days of age, equivalent to 70 percent of the grazing time in adult cattle [30,32].

On some commercial dairy farms, calves are offered free access to starter feed before weaning without forage [33], which is contrary to natural grazing. Forage inclusion in the pre-weaned calf diet has long been discouraged due to its negative effect on the growth rate $[15,17]$. However, recent research has shown that several factors need to be taken into account when evaluating the impact of forage provision on calf performance $[8,9,34]$. These factors include the source, amount, particle size, physical form, offering time, and feeding method of forage and concentrate, as well as the amount of milk offered and milk feeding method. A summary of these studies is presented in Tables 1-6. 


\subsection{Forage Factors}

Forage provision in pre-weaned calf remains a controversial topic, hence the proliferation of related research. In earlier studies, it was believed that forage was the main component in calf diets that played an essential role in rumen development [5,6]. In two different studies offering a high proportion of roughage ( $80 \%$ vs. $60 \%$ vs. $40 \%$ and $67 \%$ vs. $50 \%$ ) to calves as hay to grain respectively, Hibbs et al. [5] and Conard and Hibbs [35] found that DMI and ADG increased as the proportion of concentrate in the ration increased. Stobo et al. [36] obtained similar results with calves provided a maximum daily allowance of concentrate at $0.45,0.91,1.36,1.81$, or $2.27 \mathrm{~kg} / \mathrm{d}$ along with ad libitum access to grass hay (crude protein $(C P)=7.5 \%$, crude fiber $(C F)=28.7 \%$ ). These authors reported that as the concentrate intake increased, the hay intake decreased linearly [5,36], while live and empty body weight (BW) and rumen development were improved [36]. This is probably because concentrates result in more VFA production, especially propionate and butyrate [12], which enhances papillae development $[13,36]$. Collectively, these early studies suggested that in a high roughage feeding system, the addition of a bulky forage in the diet might decrease the consumption of energy-dense concentrates, leading to less rumen fermentation and lower degradation rates, and subsequently lower total nutrient intake and calf growth.

In the early 2000s, several studies began to investigate the effect of lower levels of forage inclusion in the diet on pre-weaned calf performance. Most of them included a proportion of forage ranging between 5 and $25 \%$ of total solid feed intake [15,19,22,27,37-40]. In contrast to previous studies, most studies either reported an increase $[19,22,38,40]$ or a lack of differences $[27,37]$ in DMI, ADG, and BW, indicative of multifactorial effects in these studies. 
Table 1. A summary of studies feeding different levels of forage in pre-weaned dairy calves.

\begin{tabular}{|c|c|c|c|c|c|c|c|c|c|c|c|c|}
\hline \multirow{2}{*}{$\begin{array}{l}\text { Objectives } \\
\text { Forage (\%) }\end{array}$} & \multirow{2}{*}{$\operatorname{Trt}^{1}$} & \multirow{2}{*}{ Calf/Trt } & \multirow{2}{*}{$\begin{array}{l}\text { Weaning } \\
\text { Age (d) }\end{array}$} & \multirow{2}{*}{$\begin{array}{c}\text { Forage Feeding } \\
\text { Age (d) }\end{array}$} & \multirow{2}{*}{ Forage Source } & \multirow{2}{*}{$\begin{array}{l}\text { Cutting Length/ } \\
\text { Processing }^{2}\end{array}$} & \multirow{2}{*}{$\begin{array}{c}\text { Solid Feed } \\
\text { Offering Method }\end{array}$} & \multirow{2}{*}{$\begin{array}{l}\text { Concentrate } \\
\text { Physical Form }\end{array}$} & \multirow{2}{*}{$\begin{array}{l}\text { Amount of } \\
\text { Milk Fed }^{3}\end{array}$} & \multicolumn{2}{|c|}{ Outcomes $^{4}$} & \multirow{2}{*}{ Reference } \\
\hline & & & & & & & & & & DMI & ADG & \\
\hline $\begin{array}{c}0,40,60 \\
80 \%\end{array}$ & 3 & 7 & 49 & 4 & $\begin{array}{l}\text { Alfalfa and } \\
\text { Timothy hay }\end{array}$ & - & TMR & - & - & $\mathbf{N}^{* *}$ & $\mathbf{N}^{* *}$ & $\begin{array}{l}\text { Hibbs et al., } \\
1956 \text { [5] }\end{array}$ \\
\hline $50,67 \%$ & 4 & 10 & 49 & 3 & $\begin{array}{l}\text { Grass legume } \\
\text { silage }\end{array}$ & - & TMR & Coarse & - & - & - & $\begin{array}{l}\text { Conard et al., } \\
1956 \text { [35] }\end{array}$ \\
\hline 5 to $60 \%$ & 10 & 4 & - & 56 & $\begin{array}{l}\text { Barley, Rye, } \\
\text { Wheat straw }\end{array}$ & - & - & - & - & - & - & $\begin{array}{c}\text { Jahn et al., } 1970 \\
\text { [41] }\end{array}$ \\
\hline $20-70 \%$ & 2 & 6 & - & 7 & Alfalfa hay & - & TMR & - & - & - & - & $\begin{array}{c}\text { Žitnan et al., } \\
1998 \text { [42] }\end{array}$ \\
\hline $0,7.5,15 \%$ & 4 & 16 & 31 & - & Bromegrass hay & $\begin{array}{l}\text { Chopped } 8 \text { to } \\
19 \mathrm{~mm}\end{array}$ & TMR & Coarse, Ground & - & $p^{*}$ & $p^{*}$ & $\begin{array}{c}\text { Coverdale et al., } \\
2004 \text { [19] }\end{array}$ \\
\hline $0,30,60 \%$ & 8 & 8 & 70 & 10 & $\begin{array}{l}\text { Corn silage, } \\
\text { Straw, Grass, } \\
\text { Corn silage }\end{array}$ & - & TMR & Pellet starter & - & $\mathbf{N}^{* *}$ & NS & $\begin{array}{l}\text { Suárez et al., } \\
2007 \text { [43] }\end{array}$ \\
\hline $0,16 \%$ & 4 & 16 & 28 & 3 & Beet pulp & - & TMR & Pellet & $\begin{array}{c}80 \mathrm{~L} \\
\text { (Around 7\%) }\end{array}$ & NS & NS & $\begin{array}{l}\text { Porter et al., } \\
2007 \text { [37] }\end{array}$ \\
\hline $0,5 \%$ & 2 & 24 & $31-32$ & $3-4$ & Cottonseed hull & $\begin{array}{c}\text { GMPL: around } 2 \\
\mathrm{~mm}\end{array}$ & TMR & Texture & $\begin{array}{c}100 \mathrm{~L} \\
\text { (Around 10\%) }\end{array}$ & $p^{*}$ & NS & $\begin{array}{l}\text { Hill et al., } 2008 \\
\text { (Trail 1) [15] }\end{array}$ \\
\hline $0,5,10 \%$ & 4 & 12 & 28 & $3-4$ & $\begin{array}{l}\text { Cottonseed hull, } \\
\text { Timothy hay }\end{array}$ & $\begin{array}{l}\text { GMPL: around } \\
2.2 \mathrm{~mm}\end{array}$ & TMR & Texture & $\begin{array}{c}120 \mathrm{~L} \\
\text { (Around } 10 \% \text { ) }\end{array}$ & $\mathbf{N}^{* *}$ & $\mathbf{N}^{* *}$ & $\begin{array}{l}\text { Hill et al., } 2008 \\
\text { (Trail 2) [15] }\end{array}$ \\
\hline $0,2.5,5 \%$ & 3 & 16 & 28 & $3-4$ & Timothy hay & $\begin{array}{l}\text { GMPL: around } \\
2.2 \mathrm{~mm}\end{array}$ & Free Choice & Texture & $\begin{array}{c}120 \mathrm{~L} \\
\text { (Around 10\%) }\end{array}$ & $\mathbf{N}^{* *}$ & $\mathbf{N}^{* *}$ & $\begin{array}{c}\text { Hill et al., 2008 } \\
\text { (Trail 3) [15] }\end{array}$ \\
\hline $0,5,10 \%$ & 6 & 7 & 53 & 3 & Alfalfa hay & GMPL: $2.6 \mathrm{~mm}$ & TMR & Finely ground & Around $10 \%$ & $p^{* *}$ & $p^{* *}$ & $\begin{array}{c}\text { Beiranvand et al., } \\
2014 \text { [22] }\end{array}$ \\
\hline $8,16 \%$ & 5 & 10 & 51 & 16 & Alfalfa hay & $\begin{array}{l}\text { GMPL: } 2.92 \text { vs. } \\
5.04 \mathrm{~mm}\end{array}$ & TMR & Ground & $\begin{array}{c}190 \mathrm{~L} \\
\text { (Around 10\%) }\end{array}$ & - & - & $\begin{array}{c}\text { Mirzaei et al., } \\
2015 \text { [27] }\end{array}$ \\
\hline $0,12.5,25 \%$ & 4 & 15 & 51 & 3 & Alfalfa hay & GMPL: $3 \mathrm{~mm}$ & TMR & Finely ground & $\begin{array}{c}204 \mathrm{~L} \\
\text { (Around 10\%) }\end{array}$ & $p^{* *}$ & $p^{* *}$ & $\begin{array}{l}\text { Nemati et al., } \\
2016 \text { [38] }\end{array}$ \\
\hline $\begin{array}{l}0,75 \% \\
100 \%\end{array}$ & 3 & 15 & 56 & 1 & Corn silage & - & TMR & Texture & $\begin{array}{c}416 \mathrm{~L} \\
\text { (Around 18\%) }\end{array}$ & NS & NS & $\begin{array}{l}\text { Kehoe et al., } \\
2019 \text { [44] }\end{array}$ \\
\hline
\end{tabular}




\subsubsection{Forage Level and Source}

Coverdale et al. [19] conducted two experiments in which starter supplemented with relatively low level (7.5 and 15\%) of bromegrass hay appeared to improve DMI, ADG, and feed efficiency (FE). In experiment 1, limited amounts of mixed feed (concentrate and forage) were offered before weaning, followed by ad libitum feeding post-weaning. Calves receiving coarse starter with either 7.5 and $15 \%$ of bromegrass hay ( 8 to $19 \mathrm{~mm}$ ) were heavier and had greater ADG and FE than calves receiving only coarse starter, while calves fed $7.5 \%$ of hay tended to have the highest ADG and FE [19]. In experiment 2 , calves were offered diets ad libitum and weaned according to intake. The concentrate and total DMI tended to be higher in calves fed 7.5 and $15 \%$ of bromegrass hay when compared with the non-forage group [19]. Similarly, Hosseini et al. [40] recently reported that compared to non or $15 \%$ straw, feeding $7.5 \%$ of chopped wheat straw tended to improve the overall total solid feed intake $(659,685$, and $826 \mathrm{~g} / \mathrm{d}$, respectively) and ADG $(519,553$, and $620 \mathrm{~g} / \mathrm{d}$, respectively) when calves were offered $4 \mathrm{~L}$ of whole milk per day. Feeding alfalfa hay at $10 \%$ of total solid feed increased the overall DMI, ADG, and final BW, and thereby shortened the time to weaning at a target DMI of starter ( $1 \mathrm{~kg}$ for 3 consecutive days), compared with feeding 0 or $5 \%$ of alfalfa hay [22]. Nemati et al. [38] also observed a linear increase in total DMI and ADG during the postweaning (d 52 to 70) and overall periods ( 3 to 70 ) of calves supplemented with chopped alfalfa hay at $0,12.5$, and $25 \%$ on dry matter (DM) basis. However, gut fill could be a confounding factor when evaluating the effect of forage feeding on improving ADG in dairy calves. It is commonly believed that an increase in ADG and BW in calves fed forage could be due to greater gut fill $[15,20,27]$. Therefore, there is a need for further investigation of the relationship between gut fill and ADG.

Poor performance has also been commonly observed when including forage in the diet $[15,17]$. Hill et al. [15] reported that feeding either 2.5 and 5\% of chopped timothy hay linearly reduced starter intake, ADG, empty body weight ADG, and FE. The quality of forage significantly influences the digestibility and the palatability of the diet [46]. Ülger et al. [47] compared two calf total mixed ration (TMR) diets with either $20 \%$ of a high-quality alfalfa hay $(\mathrm{CP}=18.1 \%$, acid detergent fiber $(\mathrm{ADF})=36.1 \%$ and neutral detergent fiber $(\mathrm{NDF})=44.4 \%$ on DM basis, relative feed value $(\mathrm{RFV})=127.2)$ or lower quality wheat straw $(\mathrm{CP}=3.7 \%, \mathrm{ADF}=52.4 \%$ and $\mathrm{NDF}=80.1 \%$ on $\mathrm{DM}$ basis, $\mathrm{RFV}=55.9)$ and found that the high-quality roughage improved FE and numerically increased ADG during the preweaning period. In a more recent study, Hill et al. [48] found that moderate to low-quality grass hay $(5.4 \% \mathrm{CP}$ and $62.8 \%$ NDF on DM basis) reduced the digestibility of DM, OM, and CP in young calves consuming a textured starter. It is noteworthy that the type of hay was not specified in this study, and we speculated that timothy or mixed hay was included based on other studies at the same period by the authors [49]. On the contrary, Castells et al. [21] and Hosseini et al. [40] reported that a low-quality straw $(\mathrm{CP}=4.2 \%$, and NDF $=74.0 \%$ on DM basis) could also improve DMI and ADG. The inconsistency in results on calf performance when providing low-quality hay was likely due to the different amount of milk offered, which may affect the solid feed consumption and forage preference as discussed below. 
Table 2. A summary of studies feeding different forage sources in pre-weaned dairy calves.

\begin{tabular}{|c|c|c|c|c|c|c|c|c|c|c|c|c|}
\hline \multirow{2}{*}{$\begin{array}{c}\text { Objectives } \\
\begin{array}{l}\text { Forage } \\
\text { Source }\end{array}\end{array}$} & \multirow[b]{2}{*}{$\operatorname{Trt}^{1}$} & \multirow[b]{2}{*}{ Calf/Trt } & \multirow{2}{*}{$\begin{array}{l}\text { Weaning } \\
\text { Age (d) }\end{array}$} & \multirow{2}{*}{$\begin{array}{c}\text { Forage Feeding } \\
\text { Age (d) }\end{array}$} & \multirow{2}{*}{ Forage (\%) } & \multirow{2}{*}{$\begin{array}{l}\text { Cutting Length/ } \\
\text { Processing }^{2}\end{array}$} & \multirow{2}{*}{$\begin{array}{c}\text { Solid Feed } \\
\text { Offering Method }\end{array}$} & \multirow{2}{*}{$\begin{array}{l}\text { Concentrate } \\
\text { Physical Form }\end{array}$} & \multirow{2}{*}{$\begin{array}{l}\text { Amount of } \\
\text { Milk Fed }^{3}\end{array}$} & \multicolumn{2}{|c|}{ Outcomes $^{4}$} & \multirow[b]{2}{*}{ Reference } \\
\hline & & & & & & & & & & DMI & ADG & \\
\hline $\begin{array}{l}\text { Alfalfa hay, } \\
\text { Cottonseed }\end{array}$ & 3 & 24 & - & 7 & $\begin{array}{c}25 \% \text { of } \\
\text { Cottonseed, Ad } \\
\text { libitum of alfalfa } \\
\text { hay }\end{array}$ & $\begin{array}{c}\text { Chopped to } 10 \\
\mathrm{~cm}\end{array}$ & Free choice & - & Around 7\% & NS & NS & $\begin{array}{l}\text { Anderson et al., } \\
\quad 1982 \text { [50] }\end{array}$ \\
\hline $\begin{array}{l}\text { Beet pulp, } \\
\text { Soybean } \\
\text { hulls, Corn } \\
\text { grits }\end{array}$ & 5 & 32 & 84 & - & $\begin{array}{c}0,30.3,46.4 \\
\quad 91.3 \%\end{array}$ & - & TMR & Pellet & $\begin{array}{l}608 \mathrm{~L} \text { (around } \\
18 \% \text { ) }\end{array}$ & $p^{* *}$ & $p^{* *}$ & $\begin{array}{l}\text { Suárez et al., } \\
2006 \text { [51] }\end{array}$ \\
\hline $\begin{array}{l}\text { Straw; Corn } \\
\text { silage, } \\
\text { Dried grass }\end{array}$ & 8 & 8 & 70 & 10 & - & Chopped & TMR & Pellet starter; & - & $\mathbf{N}^{* *}$ & NS & $\begin{array}{l}\text { Suárez et al., } \\
2007 \text { [43] }\end{array}$ \\
\hline Beet pulp & 4 & 16 & 28 & 3 & $0,16 \%$ & - & TMR & Pellet & $\begin{array}{c}80 \mathrm{~L} \\
\text { (Around 7\%) }\end{array}$ & NS & NS & $\begin{array}{l}\text { Porter et al., } \\
2007 \text { [37] }\end{array}$ \\
\hline $\begin{array}{l}\text { Cottonseed } \\
\text { hull }\end{array}$ & 2 & 24 & $31-32$ & $3-4$ & $0,5 \%$ & $\begin{array}{c}\text { GMPL: around } 2 \\
\mathrm{~mm}\end{array}$ & TMR & Texture & $\begin{array}{c}100 \mathrm{~L} \\
\text { (Around 10\%) }\end{array}$ & $p^{*}$ & NS & $\begin{array}{l}\text { Hill et al., 2008 } \\
\text { (Trail 1) [15] }\end{array}$ \\
\hline $\begin{array}{c}\text { Cottonseed } \\
\text { hull, } \\
\text { Timothy } \\
\text { hay }\end{array}$ & 4 & 12 & 28 & $3-4$ & $0,5,10 \%$ & $\begin{array}{l}\text { GMPL: around } \\
2.2 \mathrm{~mm}\end{array}$ & TMR & Texture & $\begin{array}{c}120 \mathrm{~L} \\
\text { (Around } 10 \% \text { ) }\end{array}$ & $\mathbf{N}^{* *}$ & $\mathbf{N}^{* *}$ & $\begin{array}{l}\text { Hill et al., 2008 } \\
\text { (Trail 2) [15] }\end{array}$ \\
\hline $\begin{array}{c}\text { Timothy } \\
\text { hay }\end{array}$ & 3 & 16 & 28 & $3-4$ & $0,2.5,5 \%$ & $\begin{array}{l}\text { GMPL: around } \\
2.2 \mathrm{~mm}\end{array}$ & Free Choice & Texture & $\begin{array}{c}120 \mathrm{~L} \\
\text { (Around } 10 \% \text { ) }\end{array}$ & $\mathbf{N}^{* *}$ & $\mathbf{N}^{* *}$ & $\begin{array}{l}\text { Hill et al., 2008 } \\
\text { (Trail 3) [15] }\end{array}$ \\
\hline Alfalfa hay & 6 & 7 & 53 & 3 & $0,5,10 \%$ & GMPL: $2.6 \mathrm{~mm}$ & TMR & Finely ground & Around $10 \%$ & $p^{* *}$ & $p^{* *}$ & $\begin{array}{l}\text { Beiranvand et al., } \\
2014 \text { [22] }\end{array}$ \\
\hline Alfalfa hay & 4 & 15 & 51 & 3 & $0,12.5,25 \%$ & GMPL: $3 \mathrm{~mm}$ & TMR & Finely ground & $\begin{array}{c}204 \mathrm{~L} \\
\text { (Around 10\%) }\end{array}$ & $p^{* *}$ & $p^{* *}$ & $\begin{array}{l}\text { Nemati et al., } \\
2016 \text { [38] }\end{array}$ \\
\hline $\begin{array}{c}\text { Alfalfa hay, } \\
\text { Ryegrass } \\
\text { hay }\end{array}$ & 3 & 20 & 57 & $14.1 \pm 4.2$ & Ad libitum & Chopped & Free choice & Pellet & $\begin{array}{c}214 \mathrm{~L} \\
\text { (Around 9.6\%) }\end{array}$ & NS & NS & $\begin{array}{l}\text { Castells et al., } \\
2012 \\
\text { (Trail 1) [21] }\end{array}$ \\
\hline $\begin{array}{l}\text { Oat hay, } \\
\text { Barley } \\
\text { straw, }\end{array}$ & 3 & 20 & 57 & $14.1 \pm 4.2$ & Ad libitum & Chopped & Free choice & Pellet & $\begin{array}{c}214 \mathrm{~L} \\
\text { (Around 9.6\%) }\end{array}$ & $p^{* *}$ & $p^{* *}$ & $\begin{array}{l}\text { Castells et al., } \\
2012 \\
\text { (Trail 2) [21] }\end{array}$ \\
\hline $\begin{array}{l}\text { Triticale } \\
\text { silage, Corn } \\
\text { silage }\end{array}$ & 3 & 20 & 57 & $14.1 \pm 4.2$ & Ad libitum & Chopped & Free choice & Pellet & $\begin{array}{c}214 \mathrm{~L} \\
\text { (Around 9.6\%) }\end{array}$ & $p^{* *}$ & $p^{* *}$ & $\begin{array}{l}\text { Castells et al., } \\
2012 \\
\text { (Trail 3) [21] }\end{array}$ \\
\hline
\end{tabular}


Table 2. Cont

\begin{tabular}{|c|c|c|c|c|c|c|c|c|c|c|c|c|}
\hline \multirow{2}{*}{\begin{tabular}{|c|} 
Objectives \\
Forage \\
Source
\end{tabular}} & \multirow[b]{2}{*}{$\operatorname{Trt}^{1}$} & \multirow[b]{2}{*}{ Calf/Trt } & \multirow{2}{*}{$\begin{array}{l}\text { Weaning } \\
\text { Age (d) }\end{array}$} & \multirow{2}{*}{$\begin{array}{c}\text { Forage Feeding } \\
\text { Age (d) }\end{array}$} & \multirow[b]{2}{*}{ Forage (\%) } & \multirow{2}{*}{$\begin{array}{l}\text { Cutting Length/ } \\
\text { Processing }{ }^{2}\end{array}$} & \multirow{2}{*}{$\begin{array}{c}\text { Solid Feed } \\
\text { Offering Method }\end{array}$} & \multirow{2}{*}{$\begin{array}{l}\text { Concentrate } \\
\text { Physical Form }\end{array}$} & \multirow{2}{*}{$\begin{array}{l}\text { Amount of } \\
\text { Milk Fed }^{3}\end{array}$} & \multicolumn{2}{|c|}{ Outcomes $^{4}$} & \multirow[b]{2}{*}{ Reference } \\
\hline & & & & & & & & & & DMI & ADG & \\
\hline $\begin{array}{l}\text { Alfalfa hay; } \\
\text { Oat hay }\end{array}$ & 3 & 5 & 56 & 3 & Ad libitum & Chopped & Free choice & Pellet & $\begin{array}{c}214 \mathrm{~L} \\
\text { (Around 10\%) }\end{array}$ & NS & NS & $\begin{array}{c}\text { Castells et al., } \\
2013 \text { [52] }\end{array}$ \\
\hline Oat Hay & 4 & 16 & 51 & $9 \pm 4.4$ & $\begin{array}{c}\text { Ad libitum (4, } \\
5 \%)\end{array}$ & Chopped & Free choice & Pellet & $\begin{array}{c}152 \mathrm{~L} \\
\text { (Around 10\%) }\end{array}$ & $p^{* *}$ & $p^{* *}$ & $\begin{array}{l}\text { Terré et al., } \\
2013 \text { [53] }\end{array}$ \\
\hline $\begin{array}{c}\text { Orchard } \\
\text { hay, } \\
\text { Timothy } \\
\text { hay }\end{array}$ & 2 & 8 & 56 & 42 & $0,20 \%$ & - & - & - & $\begin{array}{c}88 \mathrm{~L} \\
\text { (Around } 4 \% \text { ) }\end{array}$ & NS & - & $\begin{array}{l}\text { Kim et al., } \\
2016 \text { [54] }\end{array}$ \\
\hline $\begin{array}{c}\text { Wheat } \\
\text { straw, } \\
\text { Alfalfa hay }\end{array}$ & 2 & 15 & 56 & 14 & $20 \%$ & $\begin{array}{c}\text { Chopped to } 1-2 \\
\mathrm{~cm}\end{array}$ & TMR & Pellet & $\begin{array}{c}212 \mathrm{~L} \\
\text { (Around 10\%) }\end{array}$ & - & - & $\begin{array}{l}\text { Ülger et al., } \\
2017 \text { [47] }\end{array}$ \\
\hline $\begin{array}{l}\text { Alfalfa hay, } \\
\text { Beet pulp }\end{array}$ & 2 & 13 & 50 & 4 & $0,10,20 \%$ & - & TMR & Texture & $\begin{array}{c}228 \mathrm{~L} \\
\text { (Around 11\%) }\end{array}$ & $p^{*}$ & $p^{* *}$ & $\begin{array}{c}\text { Maktabi et al., } \\
2016 \text { [39] }\end{array}$ \\
\hline $\begin{array}{l}\text { Alfalfa hay, } \\
\text { Corn silage }\end{array}$ & 6 & 10 & 49 & 3 & $0,15 \%$ & $\begin{array}{l}\text { GMPL: } 2.9 \text { and } \\
12.07 \mathrm{~mm}\end{array}$ & TMR & Fine ground & $\begin{array}{c}196 \mathrm{~L} \\
\text { (Around 10\%) }\end{array}$ & $p^{* *}$ & $p^{* *}$ & $\begin{array}{l}\text { Mirzaei et al., } \\
2017 \text { [55] }\end{array}$ \\
\hline $\begin{array}{c}\text { Fresh } \\
\text { Ryegrass }\end{array}$ & 4 & 6 & 49 & $7-10$ & Ad libitum & $\begin{array}{l}\text { Chopped to } \\
\text { approximately } 4 \\
\mathrm{~cm}\end{array}$ & Free choice & Pellet & - & NS & NS & $\begin{array}{l}\text { Phillips et al., } \\
2004 \text { [56] }\end{array}$ \\
\hline $\begin{array}{l}\text { Coastal } \\
\text { Bermuda } \\
\text { grass hay }\end{array}$ & 2 & 16 & 56 & $17 \pm 3$ & Ad libitum (15\%) & Chopped to $5 \mathrm{~cm}$ & Free choice & Pellet & $\begin{array}{c}426 \mathrm{~L} \\
\text { (Around 19\%) }\end{array}$ & NS & NS & $\begin{array}{l}\text { Horvath et al., } \\
2019 \text { [57] }\end{array}$ \\
\hline Grass hay & 4 & 4 & 42 & 3 & Ad libitum & $\begin{array}{l}\text { Long (without } \\
\text { details) }\end{array}$ & Free choice & Texture & $\begin{array}{c}182 \mathrm{~L} \\
\text { (Around } 10 \% \text { ) }\end{array}$ & NS & NS & $\begin{array}{l}\text { Hill et al., } \\
\text { 2019a [48] }\end{array}$ \\
\hline $\begin{array}{l}\text { Corn silage, } \\
\text { Reconstituted } \\
\text { alfalfa, } \\
\text { Reconstituted } \\
\text { beet pulp }\end{array}$ & 3 & 18 & 49 & 3 & $10 \%$ & $\begin{array}{l}\text { GMPL: alfalfa, } 5 \\
\mathrm{~mm} \text { and corn } \\
\text { silage, } 12-15 \mathrm{~mm}\end{array}$ & TMR & Ground & $\begin{array}{c}283 \mathrm{~L} \\
\text { (Around 14.5\%) }\end{array}$ & - & - & $\begin{array}{l}\text { Kagar et al., } \\
2019[58,59]\end{array}$ \\
\hline
\end{tabular}

${ }^{1}$ Trt $=$ Treatment. ${ }^{2}$ GMPL refers to geometric mean particle length, which was determined using ASABE forage sieve methods (ANSI/ASAE S424.1) [45]. ${ }^{3}$ Amount of milk fed is the total amount fed during the whole trial period, while milk feeding rate equals the average daily milk allowance/birth body weight (\%). ${ }^{4}$ Outcomes $=$ effect of forage inclusion, ${ }^{* *}$ indicates a significant effect $(p<0.05),{ }^{*}$ indicates a tendency $(p<0.1)$, N indicates a negative effect, $p$ indicates positive effect, and NS shows no significant effect. DMI and ADG were evaluated by comparing calves fed with or without forage. 
Castells et al. [21] evaluated ad libitum provision of different types of forages in the diets from 2 weeks of age and found that the inclusion of alfalfa hay $(\mathrm{CP}=16.6 \%, \mathrm{ADF}=30.2 \%$, and $\mathrm{NDF}=40.2 \%$ on $\mathrm{DM}$ basis), rye-grass hay ( $\mathrm{CP}=6.8 \%, \mathrm{ADF}=35.1 \%$, and $\mathrm{NDF}=59.3 \%$ on $\mathrm{DM}$ basis $)$, oat hay $(\mathrm{CP}=8.4 \%, \mathrm{ADF}=31.8 \%$, and $\mathrm{NDF}=59.6 \%$ on $\mathrm{DM}$ basis $)$, barley straw $(\mathrm{CP}=4.2 \%, \mathrm{ADF}=42.5 \%$, and $\mathrm{NDF}=74.0 \%$ on $\mathrm{DM}$ basis $)$, corn silage $(\mathrm{CP}=8.6 \%$, $\mathrm{ADF}=25.2 \%$, and $\mathrm{NDF}=41.9 \%$ on $\mathrm{DM}$ basis), or triticale silage ( $\mathrm{CP}=7.5 \%, \mathrm{ADF}=42.3 \%$, and $\mathrm{NDF}=64.7 \%$ on $\mathrm{DM}$ basis) resulted in similar or increased intake and gains without impairing FE and nutrient digestibility. Increased DMI and ADG were observed when oat hay, barley straw, or triticale silage were offered, and the inclusion of alfalfa hay did not exhibit similar benefits, probably due to the preference for this high-quality and palatable forage [21]. Indeed, forage intake was highest in calves fed alfalfa hay (14\% of total solid $\mathrm{DM}$ ) compared with the other treatments (oat hay: $8 \%$ rye-grass hay: $4 \%$, barley straw: $5 \%$, corn silage: $5 \%$, and triticale silage: $4 \%$ ). The higher proportion of forage to concentrate ratio may limit the DM digestibility and hence restrict the DMI and ADG, as we have already discussed [5,35]. More recently, a meta-analysis by Imani et al. [34] evaluating the effect of forage provision on growth performance of dairy calves using 27 published studies from 1998 to 2016 revealed that concentrate DMI was higher in calves offered alfalfa hay compared with those offered other types of forages.

\subsubsection{Forage Physical Forms and Processing}

The focus is not only on the forage source and level of feeding, but also on the physical form and processing of forage. Mirzaei et al. [27] evaluated the effects of particle size (short at $2.92 \mathrm{~mm}$ vs. long at $5.04 \mathrm{~mm}$ as geometrical means) of alfalfa hay on growth performance of dairy calves at two different inclusion rates (low at $8 \%$ vs. high at $16 \%$ on DM basis). The authors observed no differences in growth rates between calves fed with or without hay, but greater DMI and weaning BW were found in calves fed low levels of alfalfa with a long particle size $(8 \%$ and $5.04 \mathrm{~mm})$ and high levels with a short particle size $(16 \%$ and $2.92 \mathrm{~mm})$ compared with calves fed low levels with a short particle size $(8 \%$ and $2.92 \mathrm{~mm})$ and high levels with a long particle size $(16 \%$ and $5.04 \mathrm{~mm})$. The short particle size at a low level of alfalfa might not have the potential to increase the capacity, motility, and development of the rumen $[11,60]$, while the negative effect on performance by the long particle size at a high level might be attributed to the lower digestibility rate of long particles compared with short particles [61]. Montoro et al. [62] also found that when calves were supplemented with $10 \%$ of long chopped ( 3 to $4 \mathrm{~cm}$ ) ryegrass hay, DMI, ADG, and FE were greater than those fed $10 \%$ finely ground $(2 \mathrm{~mm})$ grass hay. Longer particle size improved performance [8], probably because of the increased rumination time of calves, which increased saliva production, and consequently improved buffering effect on the ruminal environment $[63,64]$. However, inconsistent results have been obtained by Omidi-Mirzaei [65] and Suárez-Mena [66]. Omidi-Mirzaei et al. [65] reported that when calves were fed forage with different particle size (alfalfa hay: short $=1.96 \mathrm{~mm}$ or long $=3.93 \mathrm{~mm}$; and wheat straw: short $=2.03 \mathrm{~mm}$ or long $=4.10 \mathrm{~mm}$ as geometric mean), rumination time increased in calves fed forage with long particle size, but concentrate DMI, ADG, and FE were not affected. Suárez-Mena et al. [66] compared four different particle sizes $(0.82,3.04,7.10$, and $12.7 \mathrm{~mm}$ as geometric mean) of low-quality forage ( $5 \%$ straw) mixed in the diet and observed no effect on DMI, growth performance, and minimal changes in rumen fermentation and $\mathrm{pH}$ among treatments. In summary, these results imply that interactions may exist among forage source, level, and particle size, and the optimal inclusion level of forage should be determined based on the forage source and particle size.

In recent years, attempts have been made on alternative ways to increase solid feed consumption of dairy calves, such as using non-forage fiber [39], silage based feed [55,67], moisturized starter [68,69], and reconstituted hay $[58,59,70]$. Beet pulp is a common source included in the diet as a non-effective fiber source. Maktabi et al. [39] observed that $10 \%$ of beet pulp in the diet improved DMI and ADG compared to a control group (no fiber inclusion), but growth was not enhanced when $20 \%$ of beet pulp was used. Inclusion of corn silage early in life of dairy calves has recently gained more interest $[55,67]$. In an experiment that compared supplementing 15 against $0 \%$ of corn silage, DMI, 
ADG, and BW increased probably because of the higher moisture content of corn silage that contributed to reduced dustiness and increased palatability of the feed $[55,67]$. However, feeding a high level of corn silage ( 30 or $60 \% ; 75$ or $100 \%$ ) offered no benefits compared with feeding concentrate alone [43,44]. Suárez et al. [43] reported that substitution of 30 or $60 \%$ of the concentrate by corn silage did not affect DMI and ADG but feeding 30\% of straw reduced DMI. Kehoe et al. [44] also found no differences in DMI and ADG when including 0,75 , or $100 \%$ of corn silage in pre-weaned calf diet but fed solely corn silage diet stunted the growth of rumen papillae and tended to impair intestinal morphology. Hence, it is possible that corn silage can be used to partly replace the concentrate with little harmful effects on the growth and development of the calf.

It has been documented that moisturizing the concentrate starter feed by adding water to change the DM from 90 to $50 \%$ increased DMI, ADG, and VFA production in dairy calves $[68,69]$. More recently, hay processing by reconstituting with water was evaluated in a series of studies published by Kargar et al. [58,59,70,71]. Hay was soaked in water for $24 \mathrm{~h}$ and mixed every $6 \mathrm{~h}$ to obtain a theoretical DM content of $20 \%$ [71]. This method has been used previously in the diets of mature cows to increase fecal consistency [72] and reduce digestion lag time in the rumen as a result of a higher fiber digestibility [73]. Kargar et al. [70,71] replaced dry alfalfa hay $(10 \%)$ with a similar amount of reconstituted alfalfa hay, resulting in similar DMI and ADG, but higher NDF digestibility during the pre-weaned period. Furthermore, a greater improvement in health status (fecal score and general appearance score) was obtained with reconstituted hay, possibly due to decreased dustiness, similar to corn silage [70]. Therefore, corn silage, reconstituted hay, and beet pulp can be used interchangeably in dairy calf diets based on availability and the relative feed price $[58,59]$. 
Table 3. A summary of studies related to forage particle size and methods of processing forage in pre-weaned dairy calves.

\begin{tabular}{|c|c|c|c|c|c|c|c|c|c|c|c|c|}
\hline \multirow{2}{*}{$\begin{array}{c}\text { Objectives } \\
\text { Cutting } \\
\text { Length/ } \\
\text { Processing }{ }^{1}\end{array}$} & \multirow[b]{2}{*}{$\operatorname{Trt}^{2}$} & \multirow[b]{2}{*}{ Calf/Trt } & \multirow[b]{2}{*}{$\begin{array}{l}\text { Weaning } \\
\text { Age (d) }\end{array}$} & \multirow[b]{2}{*}{$\begin{array}{l}\text { Forage Feeding } \\
\text { Age (d) }\end{array}$} & \multirow[b]{2}{*}{ Forage Source } & \multirow[b]{2}{*}{ Forage $(\%)$} & \multirow[b]{2}{*}{$\begin{array}{c}\text { Solid Feed } \\
\text { Offering Method }\end{array}$} & \multirow[b]{2}{*}{$\begin{array}{l}\text { Concentrate } \\
\text { Physical Form }\end{array}$} & \multirow[b]{2}{*}{$\begin{array}{l}\text { Amount of } \\
\text { Milk Fed }^{3}\end{array}$} & \multicolumn{2}{|c|}{ Outcomes $^{4}$} & \multirow[b]{2}{*}{ Reference } \\
\hline & & & & & & & & & & DMI & ADG & \\
\hline $\begin{array}{c}\text { Chopped } \\
\text { (GMPL, } \\
5.4 \mathrm{~mm} \text { ) vs. } \\
\text { Pelleted } \\
\text { (GMPL, } \\
5.8 \mathrm{~mm})\end{array}$ & 3 & 11 & 76 & 3 & Alfalfa hay & $0,10 \%$ & TMR & Semi-texture & $500 \mathrm{~L}(17 \%)$ & NS & NS & $\begin{array}{l}\text { Jahani-Moghadam et al., } \\
2015 \text { [26] }\end{array}$ \\
\hline $\begin{array}{l}\text { GMPL: } 2.92 \\
\text { vs. } 5.04 \mathrm{~mm}\end{array}$ & 5 & 10 & 51 & 16 & Alfalfa hay & $8,16 \%$ & TMR & Ground & $\begin{array}{c}190 \mathrm{~L} \\
\text { (Around 10\%) }\end{array}$ & - & - & Mirzaei et al., 2015 [27] \\
\hline $\begin{array}{c}\text { GMPL: } 0.82, \\
3.04,7.0 \\
12.7 \mathrm{~mm}\end{array}$ & 4 & 10 & 56 & 1 & Straw & $5 \%$ & TMR & Pellet & Around $12 \%$ & - & - & $\begin{array}{l}\text { Suárez -Mena et al., } \\
\quad 2015 \text { [66] }\end{array}$ \\
\hline $\begin{array}{c}\text { GMPL: } \\
\text { Alfalfa }(1.96 \\
\text { and } 3.93 \mathrm{~mm}) \\
\text { vs. Wheat } \\
\text { straw }(2.03 \\
\text { and } 4.10 \mathrm{~mm})\end{array}$ & 4 & 12 & 49 & 1 & $\begin{array}{l}\text { Alfalfa; Wheat } \\
\text { straw }\end{array}$ & Ad libitum & Free choice & Texture & $\begin{array}{c}279 \mathrm{~L} \\
\text { (Around 14\%) }\end{array}$ & - & - & $\begin{array}{l}\text { Omidi-Mirzaei et al., } \\
2018 \text { [65] }\end{array}$ \\
\hline $\begin{array}{l}\text { Chopped to } \\
20 \text { to } 40 \mathrm{~cm}\end{array}$ & 2 & 24 & 42 & $2-3$ & $\begin{array}{c}\text { Timothy hay } \\
\text { (Phleum pratense) }\end{array}$ & Ad libitum & Free choice & Texture & $\begin{array}{c}178 \mathrm{~L} \\
\text { (Around 10\%) }\end{array}$ & NS & NS & Hill et al., 2019b [49] \\
\hline $\begin{array}{l}\text { Chopped } 3 \text { to } \\
4 \mathrm{~cm} \text { vs. } \\
\text { ground to } \\
2 \mathrm{~mm}\end{array}$ & 2 & 10 & 49 & 5 & Ryegrass hay & $10 \%$ & TMR & Crumb & $\begin{array}{c}200 \mathrm{~L} \\
\text { (Around 9\%) }\end{array}$ & - & - & Montoro et al., 2013 [62] \\
\hline $\begin{array}{l}\text { Non-forage } \\
\text { fiber }\end{array}$ & 4 & 16 & 28 & 3 & Beet pulp & $0,16 \%$ & TMR & Pellet, Mash & $\begin{array}{c}80 \mathrm{~L} \\
\text { (Around 7\%) }\end{array}$ & NS & NS & Porter et al., 2007 [37] \\
\hline $\begin{array}{l}\text { Non-forage } \\
\text { fiber }\end{array}$ & 2 & 13 & 50 & 4 & $\begin{array}{l}\text { Alfalfa hay, } \\
\text { Beet pulp }\end{array}$ & $0,10,20 \%$ & TMR & Texture & $\begin{array}{c}228 \mathrm{~L} \\
\text { (Around } 11 \% \text { ) }\end{array}$ & $p^{*}$ & $p^{* *}$ & Maktabi et al., 2016 [39] \\
\hline $\begin{array}{l}\text { Silage based } \\
\text { feed }\end{array}$ & 6 & 10 & 49 & 3 & $\begin{array}{l}\text { Alfalfa hay, } \\
\text { Corn silage; }\end{array}$ & $0,15 \%$ & TMR & Fine ground & $\begin{array}{c}196 \mathrm{~L} \\
\text { (Around 10\%) }\end{array}$ & $p^{* *}$ & $p^{* *}$ & Mirzaei et al., 2017 [55] \\
\hline $\begin{array}{l}\text { Silage based } \\
\text { feed }\end{array}$ & 4 & 12 & 56 & 3 & Corn silage & $0,15 \%$ & TMR & Mash, Texture & $\begin{array}{c}291 \mathrm{~L} \\
\text { (Around 13\%) }\end{array}$ & $p^{* *}$ & $p^{* *}$ & Mirzaei et al., 2016 [67] \\
\hline
\end{tabular}


Table 3. Cont.

\begin{tabular}{|c|c|c|c|c|c|c|c|c|c|c|c|c|}
\hline \multirow{2}{*}{$\begin{array}{c}\text { Objectives } \\
\text { Cutting } \\
\text { Length/ } \\
\text { Processing }{ }^{1}\end{array}$} & \multirow[b]{2}{*}{$\mathrm{Trt}^{2}$} & \multirow[b]{2}{*}{ Calf/Trt } & \multirow[b]{2}{*}{$\begin{array}{l}\text { Weaning } \\
\text { Age (d) }\end{array}$} & \multirow[b]{2}{*}{$\begin{array}{c}\text { Forage Feeding } \\
\text { Age (d) }\end{array}$} & \multirow[b]{2}{*}{ Forage Source } & \multirow[b]{2}{*}{ Forage $(\%)$} & \multirow[b]{2}{*}{$\begin{array}{c}\text { Solid Feed } \\
\text { Offering Method }\end{array}$} & \multirow[b]{2}{*}{$\begin{array}{l}\text { Concentrate } \\
\text { Physical Form }\end{array}$} & \multirow[b]{2}{*}{$\begin{array}{l}\text { Amount of } \\
\text { Milk Fed }^{3}\end{array}$} & \multicolumn{2}{|c|}{ Outcomes $^{4}$} & \multirow[b]{2}{*}{ Reference } \\
\hline & & & & & & & & & & DMI & ADG & \\
\hline $\begin{array}{c}\text { Silage based } \\
\text { feed }\end{array}$ & 3 & 15 & 56 & 1 & Corn silage & $0,75 \%, 100 \%$ & TMR & Texture & $\begin{array}{c}416 \mathrm{~L} \\
\text { (Around 18\%) }\end{array}$ & NS & NS & $\begin{array}{l}\text { Dill-McFarland et al., } \\
2019 \text { [74] }\end{array}$ \\
\hline $\begin{array}{l}\text { Silage based } \\
\text { feed }\end{array}$ & 3 & 15 & 56 & 1 & Corn silage & $0,75 \%, 100 \%$ & TMR & Texture & $\begin{array}{c}416 \mathrm{~L} \\
\text { (Around 18\%) }\end{array}$ & NS & NS & Kehoe et al., 2019 [44] \\
\hline $\begin{array}{l}\text { Reconstituted } \\
\text { hay }\end{array}$ & 3 & 18 & 49 & 3 & $\begin{array}{l}\text { Corn silage, } \\
\text { Reconstituted } \\
\text { alfalfa, } \\
\text { Reconstituted } \\
\text { beet pulp }\end{array}$ & $10 \%$ & TMR & Ground & $\begin{array}{c}283 \mathrm{~L} \\
\text { (Around } 14.5 \% \text { ) }\end{array}$ & - & - & Kagar et al., $2019[58,59]$ \\
\hline
\end{tabular}




\subsubsection{Time and Method of Offering Forage}

Time $[24,75,76]$ and method $[25,77,78]$ of offering forage are essential factors that can influence how dairy calves utilize forage. While Wu et al. [24] found no differences in DMI, ADG, and rumen development in calves fed alfalfa hay or oat hay either at day 3 or 15 of age, different outcomes were shown in two other studies, investigating the effect of age at which alfalfa hay [75] and oat hay [76] were introduced to calves. Both studies observed improved DMI and growth performance with forage provision, and the greatest growth performance and rumen development were obtained in calves offered hay from the 2 nd week rather than the 4 th or 6 th week of age $[75,76]$. Based on these studies, suggestions may be made to include alfalfa or oat hay in diets of calves as early as week 2 or even right after birth in order to improve DMI and ADG in dairy calves [24,75].

Forage have been provided as a mixture with concentrate in previous studies, while recent studies investigated calf preference to different feeds by providing forage and concentrate separately. Castell et al. [21] observed a greater DMI and ADG in calves provided forage rather than without forage. In this study, calves consumed around $5 \%$ of forage when it was offered ad libitum and separately from the concentrate. However, several studies did not observe a positive effect on DMI when part of the concentrate was substituted for forage before weaning [43,47]. In research by Ülger et al. [47], who mixed forage at $20 \%$ with the concentrate and Suárez et al. [43] at either 30 or $60 \%$, calves consumed at a predetermined fixed forage to concentrate ratio which was much greater compared to calves fed free choice. Therefore, the greater forage proportion in the mixture diet (i.e., containing 30 or $60 \%$ forage) [43] might mask the positive effect on DMI and growth performance compared with forage consumed voluntarily (around 5\% forage) by calves [21]. A meta-analysis study has proven this inference; when forage was offered separately, starter feed intake and ADG increased compared to a mixed ration diet [34]. On the contrary, some studies claimed that DMI and growth performance were not different between two feeding methods (mixed vs. separate) [77,78], possibly due to the low proportion of forage ( 15 or $10 \%$ ) in mixed ration, which was similar to that (11 or $10 \%)$ with separate forage provision in studies by Overvest [77] and EbnAli [78]. Moreover, the high level of milk feeding (around 13 or $26 \%$ of birth weight) might have decreased the solid feed consumption [77,78]. Although the forage feeding method may not always lead to better performance, it certainly affects the expression and development of dairy calf behavior [25,79], as discussed below. 
Table 4. A summary of studies differing in methods and time of offering forage in pre-weaned dairy calves.

\begin{tabular}{|c|c|c|c|c|c|c|c|c|c|c|c|c|}
\hline Objectives & & & & & & & & & & Out & 1es ${ }^{4}$ & \\
\hline $\begin{array}{c}\text { Forage } \\
\text { Feeding } \\
\text { Method/Time }\end{array}$ & $\operatorname{Trt}^{1}$ & Calf/Trt & $\begin{array}{l}\text { Weaning } \\
\text { Age (d) }\end{array}$ & $\begin{array}{l}\text { Forage Feeding } \\
\text { Age (d) }\end{array}$ & Forage Source & Forage (\%) & $\begin{array}{l}\text { Cutting Length/ } \\
\text { Processing }{ }^{2}\end{array}$ & $\begin{array}{l}\text { Concentrate } \\
\text { Physical Form }\end{array}$ & $\begin{array}{l}\text { Amount of } \\
\text { Milk Fed }^{3}\end{array}$ & DMI & ADG & Reference \\
\hline $\begin{array}{l}\text { Sole vs. } \\
\text { TMR Free } \\
\text { choice- }\end{array}$ & 4 & 12 & 50 & 1 & Grass hay & $\begin{array}{l}\text { TMR }(0,15 \%) \text {, } \\
\text { Free choice }\end{array}$ & Chopped $<2.5 \mathrm{~cm}$ & Texture & $\begin{array}{c}534 \mathrm{~L} \\
\text { (Around 26\%) }\end{array}$ & NS & NS & $\begin{array}{l}\text { Overvest et al., } \\
2015 \text { [77] }\end{array}$ \\
\hline $\begin{array}{l}\text { Sole vs. } \\
\text { TMR, Free } \\
\text { choice }\end{array}$ & 3 & 15 & 57 & 3 & Alfalfa hay & $\begin{array}{l}\text { TMR }(0,10 \%) \text {, } \\
\text { Free choice }\end{array}$ & GMPL: $3 \mathrm{~mm}$ & Finely ground & $\begin{array}{c}262 \mathrm{~L} \\
\text { (Around 11\%) }\end{array}$ & $p^{* *}$ & NS & $\begin{array}{c}\text { EbnAli et al., } \\
2016 \text { [78] }\end{array}$ \\
\hline $\begin{array}{l}\text { Sole vs. } \\
\text { Free choice }\end{array}$ & 3 & 60 & 56 & 4 & $\begin{array}{l}\text { Alfalfa hay, } \\
\text { Oats hay }\end{array}$ & Free choice & $\begin{array}{l}\text { Chopped to } \\
\text { approximately } \\
2.5 \mathrm{~cm}\end{array}$ & Pellet & $\begin{array}{c}376 \mathrm{~L} \\
\text { (Around 17\%) }\end{array}$ & NS & NS & $\begin{array}{c}\text { Xiao et al., } 2018 \\
{[25]}\end{array}$ \\
\hline $\begin{array}{l}\text { Day } 14, \\
28,42\end{array}$ & 4 & 10 & 57 & - & Alfalfa hay & TMR $(0,15 \%)$ & GMPL: $3 \mathrm{~mm}$ & Ground & Around $10 \%$ & $p^{* *}$ & $p^{* *}$ & $\begin{array}{l}\text { Hosseini et al., } \\
2015 \text { [75] }\end{array}$ \\
\hline Day 3, 15 & 5 & 8 & 56 & - & $\begin{array}{l}\text { Alfalfa hay, } \\
\text { Oats hay }\end{array}$ & Free choice & Chopped & Pellet & $\begin{array}{c}358 \mathrm{~L} \\
\text { (Around 16\%) }\end{array}$ & NS & NS & $\begin{array}{l}\text { Wu et al., } \\
2018 \text { [24] }\end{array}$ \\
\hline Day 14,42 & 3 & 6 & 63 & - & Oat hay & Free choice & - & - & $\begin{array}{c}252 \mathrm{~L} \\
\text { (Around 10\%) }\end{array}$ & $p^{* *}$ & $p^{* *}$ & $\begin{array}{l}\text { Lin et al., } \\
2018[60,76]\end{array}$ \\
\hline
\end{tabular}

${ }^{1}$ Trt $=$ Treatment. ${ }^{2}$ GMPL refers to geometric mean particle length, which was determined using ASABE forage sieve methods (ANSI/ASAE S424.1) [45]. ${ }^{3}$ Amount of milk fed is the total amount fed during the whole trial period, while milk feeding rate equals the average daily milk allowance/birth body weight $(\%) .{ }^{4}$ Outcomes $=$ effect of forage inclusion, ${ }^{* *}$ indicates a significant effect $(p<0.05), \mathrm{N}$ indicates a negative effect, $p$ indicates positive effect, and NS shows no significant effect. DMI and ADG were evaluated by comparing calves fed with or without forage. 


\subsection{Concentrate and Milk Factors}

\subsubsection{The Physical Form of Concentrate Feed}

There are different forms and types of calf starters. Porter et al. [37] reported that whether forage was included or not, calves on coarse mash (average particle size: $2014 \mu \mathrm{m}$ ) ate and gained more than those on pelleted diets (average particle size: $888 \mu \mathrm{m}$ ). Moreover, rumination was initiated earlier. Hence, up to 8 weeks of age, calves raised on a complete concentrate diet without forage did not experience a significant depression in growth performance, which might be due to the long particle size of coarse mash feed initiating rumination early and preventing bloat and parakeratosis in the rumen [65]. Two consecutive experiments were conducted by Terré et al. in 2005 to evaluate the influence of the physical form of concentrate feed (textured or pelleted) with or without forage inclusion on the performance of young calves. Calves receiving pelleted concentrate feed with straw exhibited a greater solid intake and higher rumen fluid $\mathrm{pH}$ compared with those receiving a pelleted concentrate feed without straw. Calves that received the texturized (containing whole corn) starter feed had equivalent rumen fluid $\mathrm{pH}$ to those fed a pelleted concentrate with straw. However, rumen fluid $\mathrm{pH}$ and performance were not improved when another texturized (containing rolled mixed grains) concentrate feed was offered [80]. These results show that the physical forms of concentrate feed may affect the calf performance and rumen environment differently. For example, calves fed a texturized concentrate feed containing whole corn had a greater rumen fluid $\mathrm{pH}$ than steam-flaked corn, dried-rolled corn, and roasted-rolled corn [81], likely because the calves spent a longer time chewing the whole corn feed, which increased saliva production, hence neutralizing the rumen $\mathrm{pH}$ and acids. In another study involving a mashed (with or without corn silage) and a textured concentrate (with or without corn silage), regardless of the physical form of concentrate feed, forage inclusion resulted in greater DMI, ADG, and final BW than non-included calves [67]. It was evident that forage provision had more effect on the growth performance than the physical form of the feed, whereby steam-flaked grains were the main component in the concentrate. In agreement, Mojahedi et al. [82] reported that including alfalfa hay could improve DMI and ADG of calves fed steam-flaked corn, as opposed to a cracked corn-based diet, probably because of higher amounts of gelatinized starch in the steam-flaked corn ( 44.1 vs. $12.5 \%$ of total starch, respectively). Possibly, forage inclusion enhanced starch fermentability of the steam-flaked corn through the provision of effective fiber. Collectively, a decrease in solid feed consumption in calves fed finely ground or pelleted starter on commercial farms compared with those fed textured concentrate [83] warrants forage provision to improve the solid feed intake, growth performance, and rumen environment to a greater extent $[80,82]$. 
Table 5. A summary of studies on forage inclusion in dairy calves based on different physical forms of concentrate.

\begin{tabular}{|c|c|c|c|c|c|c|c|c|c|c|c|c|}
\hline \multirow{2}{*}{$\begin{array}{c}\text { Objectives } \\
\text { Physical } \\
\text { Form of } \\
\text { Concentrate }\end{array}$} & \multirow[b]{2}{*}{$\operatorname{Trt}^{1}$} & \multirow[b]{2}{*}{ Calf/Trt } & \multirow[b]{2}{*}{$\begin{array}{l}\text { Weaning } \\
\text { Age (d) }\end{array}$} & \multirow[b]{2}{*}{$\begin{array}{c}\text { Forage Feeding } \\
\text { Age (d) }\end{array}$} & \multirow[b]{2}{*}{ Forage Source } & \multirow[b]{2}{*}{ Forage (\%) } & \multirow{2}{*}{$\begin{array}{c}\text { Forage Cutting } \\
\text { Length/ } \\
\text { Processing }\end{array}$} & \multirow[b]{2}{*}{$\begin{array}{l}\text { Solid Feed } \\
\text { Offering } \\
\text { Method }\end{array}$} & \multirow[b]{2}{*}{$\begin{array}{l}\text { Amount of } \\
\text { Milk Fed }^{3}\end{array}$} & \multicolumn{2}{|c|}{ Outcomes ${ }^{4}$} & \multirow[b]{2}{*}{ Reference } \\
\hline & & & & & & & & & & DMI & ADG & \\
\hline Pellet, Mash & 4 & 16 & 28 & 3 & Beet pulp & $0,16 \%$ & - & TMR & $\begin{array}{c}80 \mathrm{~L} \\
\text { (Around 7\%) }\end{array}$ & NS & NS & $\begin{array}{l}\text { Porter et al., } \\
2007 \text { [37] }\end{array}$ \\
\hline $\begin{array}{l}\text { Pellet, } \\
\text { Texture }\end{array}$ & 3 & 11 & 49 & 7 & Ryegrass hay & $\begin{array}{c}\text { Ad libitum }(0,6.8 \\
11.6 \%)\end{array}$ & - & Free choice & $\begin{array}{c}274 \mathrm{~L} \\
\text { (Around 16\%) }\end{array}$ & NS & NS & $\begin{array}{l}\text { Terré et al., } 2015 \\
\text { (Trail 1) [80] }\end{array}$ \\
\hline $\begin{array}{l}\text { Pellet, } \\
\text { Texture }\end{array}$ & 3 & 20 & 52 & 8 & Ryegrass hay & $\begin{array}{c}\text { Ad libitum (0, } \\
4.3 \%)\end{array}$ & - & Free choice & $\begin{array}{c}233 \mathrm{~L} \\
\text { (Around 13\%) }\end{array}$ & NS & NS & $\begin{array}{l}\text { Terré et al., } 2015 \\
\text { (Trail 2) [80] }\end{array}$ \\
\hline $\begin{array}{l}\text { Mash, } \\
\text { Texture }\end{array}$ & 4 & 12 & 56 & 3 & Corn silage & $0,15 \%$ & $\begin{array}{l}\text { GMPL: } 0.5,1.1, \\
3.0 \text {, and } 4.0 \mathrm{~mm}\end{array}$ & TMR & $\begin{array}{c}291 \mathrm{~L} \\
\text { (Around 13\%) }\end{array}$ & $p^{* *}$ & $p^{* *}$ & $\begin{array}{l}\text { Mirzaei et al., } \\
2016[67]\end{array}$ \\
\hline
\end{tabular}

${ }^{1}$ Trt $=$ Treatment. ${ }^{2}$ GMPL refers to geometric mean particle length, which was determined using ASABE forage sieve methods (ANSI/ASAE S424.1) [45]. ${ }^{3}$ Amount of milk fed is the total amount fed during the whole trial period, while milk feeding rate equals the average daily milk allowance/birth body weight (\%). ${ }^{4}$ Outcomes $=$ effect of forage inclusion, ${ }^{* *}$ indicates a significant effect $(p<0.05), \mathrm{N}$ indicates a negative effect, $p$ indicates positive effect, and NS shows no significant effect. DMI and ADG were evaluated by comparing calves fed with or without forage. 
Table 6. A summary of studies on forage inclusion in dairy calves based on different volumes and methods of milk feeding.

\begin{tabular}{|c|c|c|c|c|c|c|c|c|c|c|c|c|}
\hline \multirow{2}{*}{$\begin{array}{c}\text { Objectives } \\
\text { Milk } \\
\text { Feeding } \\
\text { Amount/ } \\
\text { Method }^{1}\end{array}$} & \multirow[b]{2}{*}{$\operatorname{Trt}^{2}$} & \multirow[b]{2}{*}{ Calf/Trt } & \multirow[b]{2}{*}{$\begin{array}{l}\text { Weaning } \\
\text { Age (d) }\end{array}$} & \multirow[b]{2}{*}{$\begin{array}{l}\text { Forage Feeding } \\
\text { Age (d) }\end{array}$} & \multirow[b]{2}{*}{ Forage Source } & \multirow[b]{2}{*}{ Forage (\%) } & \multirow[b]{2}{*}{$\begin{array}{l}\text { Cutting Length/ } \\
\text { Processing }^{3}\end{array}$} & \multirow[b]{2}{*}{$\begin{array}{l}\text { Solid Feed } \\
\text { Offering } \\
\text { Method }\end{array}$} & \multirow[b]{2}{*}{$\begin{array}{l}\text { Concentrate } \\
\text { Physical Form }\end{array}$} & \multicolumn{2}{|c|}{ Outcomes $^{4}$} & \multirow[b]{2}{*}{ Reference } \\
\hline & & & & & & & & & & DMI & ADG & \\
\hline $\begin{array}{c}359 \mathrm{~L} \\
\text { (Around 16\%), } \\
221 \mathrm{~L} \\
\text { (Around 10\%) }\end{array}$ & 4 & 8 & 56 & 1 & Beet pulp & $\begin{array}{l}\text { Beet pulp } \\
(0 \%, 18 \%)\end{array}$ & Chopped & Free choice & Pellet & NS & $\mathbf{N}^{*}$ & $\begin{array}{l}\text { Kosiorowska et al., } \\
2010 \text { [84] }\end{array}$ \\
\hline $\begin{array}{c}350 \mathrm{~L} \\
\text { (Around 20\%) }\end{array}$ & 2 & 15 & 56 & 3 & $\begin{array}{l}\text { Orchard grass } \\
\text { hay }\end{array}$ & Ad libitum & Chopped & - & - & NS & NS & $\begin{array}{l}\text { Khan et al., } \\
2011 \text { [20] }\end{array}$ \\
\hline $\begin{array}{c}534 \mathrm{~L} \\
\text { (Around 26\%) }\end{array}$ & 4 & 12 & 50 & 1 & Grass hay & $\begin{array}{l}\text { TMR }(0,15 \%), \\
\text { Free choice-ad } \\
\text { libitum }\end{array}$ & $\begin{array}{c}\text { Chopped }< \\
2.5 \mathrm{~cm}\end{array}$ & $\begin{array}{l}\text { Free choice; } \\
\text { TMR }\end{array}$ & Texture & NS & NS & $\begin{array}{l}\text { Overvest et al., } \\
2015 \text { [77] }\end{array}$ \\
\hline $\begin{array}{c}212 \mathrm{~L} \\
\text { (Around 9\%), } \\
338 \mathrm{~L} \\
\text { (Around 15\%) }\end{array}$ & 6 & 10 & 56 & 4 & Wheat straw & $0,7.5,15 \%$ & - & TMR & Ground & $p^{*}$ & $p^{*}$ & $\begin{array}{l}\text { Hosseini et al., } \\
2019 \text { [40] }\end{array}$ \\
\hline $\begin{array}{l}\text { Step Down } \\
\text { vs. } \\
\text { Conventional; } \\
313 \mathrm{~L} \\
\text { (Around } 13 \%, \text { ) }\end{array}$ & 4 & 20 & 60 & 3 & Alfalfa hay & $0,15 \%$ & - & TMR & Finely ground & $p^{* *}$ & $p^{* *}$ & $\begin{array}{c}\text { Daneshvar et al., } \\
2015 \text { [23] }\end{array}$ \\
\hline $\begin{array}{l}\text { Teat vs. } \\
\text { Bucket; } \\
241 \text { L } \\
\text { (Around 13\%) }\end{array}$ & 3 & 10 & $45 \pm 2$ & $1-3$ & Timothy hay & Ad libitum & $\begin{array}{l}\text { Chopped around } \\
5 \mathrm{~cm}\end{array}$ & - & Pellet & NS & NS & $\begin{array}{l}\text { Horvath et al., } \\
2017 \text { [85] }\end{array}$ \\
\hline
\end{tabular}

${ }^{1}$ The amount of milk fed is the total amount fed during the whole trial period, while the milk feeding rate equals the average daily milk allowance/birth body weight $(\%) .{ }^{2}$ Trt $=$ Treatment. ${ }^{3}$ GMPL refers to geometric mean particle length, which was determined using ASABE forage sieve methods (ANSI/ASAE S424.1) [45]. ${ }^{4}$ Outcomes $=$ effect of forage inclusion, ${ }^{* *}$ indicates a significant effect $(p<0.05), *$ indicates a tendency $(p<0.1)$, N indicates a negative effect, $p$ indicates positive effect, and NS shows no significant effect. DMI and ADG were evaluated by comparing calves fed with or without forage. 


\subsubsection{The Amount and Method of Milk Feeding}

Most studies that suggested exclusive concentrate feeding were conducted with calves fed low amounts of milk [15,36]. For example, in the Hill et al. [15] study, only $120 \mathrm{~L}$ of milk was fed to calves before 28 days of life (weaning date), averaging around $4 \mathrm{~L} / \mathrm{d}$ of milk (approximately $10 \%$ of birth body weight) which is insufficient for optimal growth. This low milk feeding rate might stimulate greater concentrate intake in calves to make up for the deficit in energy requirements. Indeed, a strong negative correlation between liquid and concentrate feed intake has been elucidated in a meta-analysis that shows calves fed high milk or milk replacer resulted in limited daily starter intakes [28].

As discussed earlier, compared to concentrates, forage are bulkier and are less digestible and have lower fermentation rates [5], which can lead to a low voluntary intake when low energy forage is offered separately or as a mixture with the concentrates [8,86]. Castells et al. [21] claimed that when calves were offered different forages (hay, straw, and silages, respectively) with concentrates ad libitum and separately, forage consumption was only $4-6 \%$ of the total solid feed intake. Interestingly, the proportion of hay consumed across studies seems to range from 3 to $45 \%$ of total solid feed intake $[20,21,25,52,87]$. The difference in the proportion of forage consumed across multiple studies may also depend upon milk feeding amounts. In two studies feeding different amounts of milk, Castells et al. [52] reported that calves consumed 3\% of total solid feed as forage at a low level of milk feeding (214 L from d 0 to $\mathrm{d} 57$, averaged $4 \mathrm{~L} / \mathrm{d}$, around $10 \%$ of birth body weight), while Xiao et al. [52] reported a greater ratio of forage to total solid feed intake, approximately $45 \%$ when a high amount of milk was offered ( $376 \mathrm{~L}$ from d 0 to $\mathrm{d} 56$, averaged $6.8 \mathrm{~L} / \mathrm{d}$, around $17 \%$ of birth body weight) [25]. Milk contains a high content of fat and sugar, which provide the energy required by the calves, and greater milk amounts might alter concentrate requirements [25]. This speculation concurs with another study in which calves fed low amounts of milk consumed more concentrates, resulting in a lower ratio of forage to total solid feed intake in a low compared to a high milk feeding group $(13.2 \%$ vs. $18.6 \%)$ [84].

Feeding patterns and methods could also affect forage intake in calves. When investigating the effect of either step down (fed at around 15\% of birth body weight per day) or conventional (approximately $10 \%$ of birth body weight per day) feeding patterns in dairy calves, Khan et al. [88] found that the former had better performance. In a different study, Daneshvar et al. [23] reported that when similar amounts of milk were fed using different feeding patterns (step down vs. conventional), solid feed intake did not differ between treatments. Horvath et al. [85] showed that the feeding method (bucket vs. teat feeding) did not alter the forage and concentrate intake. Hence, milk allowance might have a greater impact on solid feed consumed by calves as opposed to the milk feeding pattern or method.

Limited studies directly investigating the relationship between milk allowance and forage consumption in pre-weaned calves are available, which calls for scientists to turn their attention to this area, especially with more farms leaning towards high milk volume feeding. Forage inclusion can promote total solid feed consumption and BW gain in calves, but factors such as the amount of forage, forage sources, forage feeding method, physical form of forage and concentrate, and milk allowance might confound these benefits. Calves should be slowly introduced to relatively low levels of forage while guarding against the use of low digestible forage (i.e., straw), which may depress total DMI and BW gain. Moreover, forage should be available free-choice and in separate containers from concentrate feed.

Table 7 shows a summary of selected studies that determined the effects of forage inclusion on performance, rumen fermentation and development, and expressive behavior in dairy calves. While the effects of feeding forage on performance, such as DMI and ADG, were controversial, relatively consistent results were obtained in other parameters, like rumen fermentation and expressive behavior. 
Table 7. Summary of selected studies on forage inclusion and their effect on performance, rumen fermentation, and expressive behavior compared to calves fed only concentrates ${ }^{1}$.

\begin{tabular}{|c|c|c|c|}
\hline Parameters $^{2}$ & Studies with Positive Impact & Studies with Negative Impact & Studies with No Effect \\
\hline Total solid DMI & {$[15,18-23,38-40,43,50,51,55,67,75,76,78,80]$} & {$[5,15,17,39,43]$} & {$[21,24-26,37,44,48-50,52,54,56,57,77,80,84,86]$} \\
\hline ADG & {$[18-23,38-40,50,51,53,55,67,75,76,80]$} & {$[5,15,17,39,84]$} & {$[15,21,24-26,37,43,44,48-50,52,56,57,77,78,80,85]$} \\
\hline DM digestibility & / 1 & {$[23,37,41,48]$} & {$[21,39,52,75,78]$} \\
\hline Feed to Gain ratio & {$[19,39]$} & {$[5,15,22,51]$} & {$[21,23,24,26,27,37-40,44,49,52,53,55,56,67,75,78,80,85]$} \\
\hline Structural growth & [55] & [15] & {$[20,23,25,27,38-40,44,49,57,67,76,80]$} \\
\hline Fecal score & 1 & {$[27,37]$} & {$[19,26,39,44,49,75]$} \\
\hline Rumen fluid $\mathrm{pH}$ & {$[20,22,23,25,27,37-42,52-55,67,75,76,78,80]$} & 1 & {$[5,24,39,43]$} \\
\hline Total VFA & [22] & {$[19,23,25,35,40,52-54,67]$} & {$[24,27,38,39,42,43,76,78]$} \\
\hline Acetate & {$[22,23,40,43,52,53,67]$} & 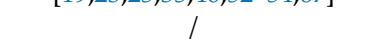 & {$[19,24,27,38,39,76,78]$} \\
\hline Propionate & [53] & {$[25,35,40,43,54,67]$} & {$[19,22-24,27,38,39,52,76,78]$} \\
\hline Butyrate & 1 & {$[23,25,27,39,40,53]$} & {$[19,22,24,38,39,43,52,54,67,76,78]$} \\
\hline Valerate & 1 & {$[23,25,52,53,67]$} & {$[40,76]$} \\
\hline Acetate to Propionate ratio & {$[27,37,38,40,42,54,67]$} & [53] & {$[19,22-24,39,52]$} \\
\hline Lactate & 1 & [51] & [43] \\
\hline $\mathrm{NH}_{3}$ & [42] & [43] & [24] \\
\hline Rumen papillae length & 1 & {$[42,44,52]$} & {$[20,22,27,37,43,76,84]$} \\
\hline Rumen plaque formation & 1 & {$[22,43]$} & [42] \\
\hline Rumen weight & {$[11,20,50]$} & {$[27,43]$} & {$[24,52,76,84]$} \\
\hline Rumen volume & {$[11,42,52]$} & 1 & {$[24,76]$} \\
\hline Ruminating & {$[21,39,40,53,55,56,75-78]$} & / & [39] \\
\hline Total eating behavior & {$[39,40,57,76,77]$} & 1 & {$[39,55,78,85]$} \\
\hline Concentrate eating behavior & [57] & {$[56,85]$} & {$[21,53,75]$} \\
\hline Drinking behavior & [76] & {$[56]$} & 1 \\
\hline Non-nutritive oral behavior/Abnormal behavior & 1 & {$[21,40,53,55-57,76,85]$} & {$[75,78]$} \\
\hline Lying behavior & 1 & {$[21,53,75,76]$} & {$[39,40,55,56,77,78]$} \\
\hline Standing behavior & [76] & 1 & {$[21,39,40,53,55,56,75,78]$} \\
\hline Satisfaction behavior & [56] & 1 & [57] \\
\hline Urination and Defecation behavior & 1 & 1 & [56] \\
\hline Sorting behavior & 1 & {$[25,87]$} & [77] \\
\hline
\end{tabular}

${ }^{1}$ Forages included dry hay, silage, straw, and by-products (e.g., cottonseed hulls) and reconstituted hay. Positive, negative, and no effect on a parameter was determined by adding forage in the diet compared with no forage inclusion in those studies. "Positive effect" represent an increase or improved effect $(p<0.05)$, "Negative effect" represent a decreased effect in the related parameter $(p<0.05)$, " $/$ " means no studies were found to affect this parameter in the current review $(p>0.05){ }^{2}$ Parameters were measured in dairy calves within 3 months of age. Non-nutritive oral behavior/abnormal behavior included tongue rolling, licking buckets, pen or surface, sniffing, vocalizing, and eating beddings; Satisfaction behavior included tail swishing, self-grooming, and rubbing. 


\section{Rumen Environment}

\subsection{Rumen Fluid $p H$ and Fermentation}

The rumen is the largest and most crucial compartment of the digestive system in adult ruminants, as it is vital for acquiring metabolic substrates through microbial fermentation. Although young calves have an undeveloped rumen, fermentation begins at a very early age [89] and may affect the development and health of the rumen. Prolonged low rumen fluid $\mathrm{pH}$ may cause subacute ruminal acidosis (SARA) in adult cows, which is well defined in beef feedlot cattle ( $\mathrm{pH}<5.8$ for $3 \mathrm{~h} / \mathrm{d}$ ) [90] and dairy cows (as periods of moderately depressed $\mathrm{pH}$, from about 5.0 to 5.5) [91]. However, in young calves, ruminal acidosis has not been clearly defined. Previous studies reported that rumen fluid $\mathrm{pH}$ in young calves is often well below 5.8 [89,92]. Some researchers believe that, as in mature cows, dairy calves can experience ruminal acidosis [34,89], probably due to the high amount of concentrate fed [92] in artificially rearing systems and the relatively low saliva [93] secreted at a young age.

Concentrate feed, high in rapidly fermentable carbohydrates, such as sugar and starch, provides energy for optimal growth, but the fermentation rate tends to generate lots of VFA and lactic acid, resulting in low rumen fluid $\mathrm{pH}$ [51]. Forage, high in fiber, may play a role in mitigating this challenge. Most of the studies (21 studies, accounting for $84 \%$ of summarized studies) explored in this review showed a positive effect of forage inclusion on rumen fluid $\mathrm{pH}$ in dairy calves, while very few reported no difference (four studies, accounting for $16 \%$ of summarized studies) or negative impact (Table 7). In agreement with a previous meta-analysis, our literature search showed that forage could improve the rumen fluid $\mathrm{pH}$ when supplemented to calves, though it might be dependent on the forage source $[38,40]$. Alfalfa hay is more likely to modulate rumen fluid $\mathrm{pH}$ during the milk-feeding period than other types of forages [33]. Maktabi et al. [39] reported that increasing fiber content by adding beet pulp $(10 \%$ and $20 \%)$ in the concentrate diet failed to improve rumen fluid $\mathrm{pH}$, while supplementing alfalfa hay $(10 \%)$ resulted in a significant improvement in this parameter by providing more effective NDF. Terré et al. [53] also demonstrated that increasing NDF content (18.2 vs. 26.7\%) by adding soybean hulls in the pelleted starter could not alter rumen fluid $\mathrm{pH}$, but adding chopped oat hay, containing more effective fiber, could improve the ruminating behavior resulting in a higher $\mathrm{pH}$. In agreement, Laarman et al. [94] reported a positive relationship between forage intake and rumen fluid pH, while SARA (rumen fluid pH below 5.8) could be exacerbated when calves are fed less than 0.08 kg/d [64], suggesting that even small amounts of forage consumption (timothy hay, $0.08 \mathrm{~kg} / \mathrm{d}$ ) can reduce rumen acidosis in calves.

The possible reasons for the increased rumen fluid $\mathrm{pH}$ when adding forage in the diet are multifactorial. On the one hand, forage is bulkier and has lower digestibility compared to the concentrate. The higher forage consumption leads to increased intake of effective fiber, which in turn stimulates the chewing (ruminating and eating) activity of calves [56,95], and subsequently improves the saliva production and rumen buffering $[38,63]$. On the other hand, the rapidly fermentable carbohydrates generate abundant VFA that may exceed and overwhelm the absorptive capacity of the undeveloped rumen [96]. Feeding forage in pre-weaned calves could reduce the concentration of VFA $[19,23,25,35,40,52-54,67]$ and decrease rumen plaque formation [42,52], increasing the absorptive surface area of the rumen epithelium and hence reducing the accumulation of VFA and maintaining the appropriate rumen fluid $\mathrm{pH}$. In addition, an increased passage rate in the rumen was observed in calves fed forage compared to those fed concentrate only, which lowered the feed retention time in the gastrointestinal tract ( $28.4 \mathrm{~h}$ for concentrate feed vs. $18.8 \mathrm{~h}$ for oat hay group), fermentation time and VFA concentration [52]. In the same study, calves fed forage tended to have a higher expression of monocarboxylate transporter-1 in the rumen wall [52], which plays a central role in transporting acetate, lactate, and protons from the rumen lumen to the bloodstream $[97,98]$, hence alleviating VFA accumulation in the rumen as well.

A greater acetate $[22,23,40,43,52,53,67]$, and a lower propionate $[25,34,40,43,54,67]$, butyrate $[23,25,27,39,40,53]$, and valerate $[23,25,52,53,67]$ concentration/proportions have been reported 
in calves fed with forage than those fed only concentrate. These dynamics in fermentation patterns are probably related to the changes in the rumen microbial ecosystem. For example, cellulolytic microbes, such as Ruminococcus flavefaciens and Ruminococcus albus, are more prevalent in animals fed high forage diets, which increase fiber degradation and elevates the proportion of acetate in the rumen [42,52]. Both propionate and butyrate stimulate and enhance rumen epithelial development $[12,13,99]$, with butyrate serving as the preferred energy source as well as modulating the gene expression in the rumen epithelium [96]. A low proportion of these two VFA may limit the growth of rumen papillae [42,52]. Due to its relatively low proportions, the valerate has received little attention. It has been suggested that cellulolytic microbes utilize valerate in the rumen [100], which might explain its decrease in calves supplemented with forage in their diets.

Lactic acid decreases in the rumen when forage is included in the diet [51], which might end up positively altering rumen fluid $\mathrm{pH}$. Terré et al. [53] found an interesting relationship between rumen VFA and rumen fluid $\mathrm{pH}$. When rumen fluid $\mathrm{pH}$ was above 5.1, total VFA and rumen fluid $\mathrm{pH}$ were linearly correlated; however, when it fell below 5.1, the correlation disappeared. The implications are that lactic acid (a much stronger acid than VFA) may alter rumen fluid $\mathrm{pH}$ at a pH below 5.1 [53,101]. In adult cows, an acute ruminal acidosis was observed, with excessive consumption of concentrate feed leading to a sudden and uncompensated drop in rumen fluid pH (below about 5.0). Owens et al. [60] showed that lactic acid concentrations increased with a decline in rumen fluid $\mathrm{pH}$. However, when rumen fluid pH (around 5.0-5.5) was moderately depressed, lactic acid accumulation was inconsistent [102] or transiently fluctuated [103]. Hence, although moderate depression in rumen fluid pH may cause SARA in dairy cows, it is not because of the lactic acid accumulation, but might be due to the accumulation of VFA alone [102].

Collectively, previous studies demonstrate that forage provision has a positive effect on rumen fluid $\mathrm{pH}$ and alters rumen fermentation in calves. However, the majority of these studies assessed rumen fluid $\mathrm{pH}$ and VFA at only a single time point. Further research is encouraged to test the dynamic changes in rumen fluid $\mathrm{pH}$ and VFA when different types, amounts, timing, and particle sizes of forage are supplemented in the diet, which may help us define SARA in young calves more accurately.

\subsection{Rumen Microbes}

A developed rumen is full of microorganisms that ferment and degrade multiple nutritional fractions (sugar, starch, fiber, protein, fat, and so on) and provides necessary metabolic substrates and nutrients to the dairy cattle. The microbial ecosystem differs between young calves and adult cows [104]. At birth, young calves possess no anaerobic microorganisms in the rumen [105], with recent evidence suggesting that colonization occurs immediately after birth $[104,106]$. Dominant microbes that are involved in normal rumen function of mature cows are present as early as one day of age [106]. This colonization of microorganisms and the presence of substrates trigger fermentation activity, which then provides indispensable nutrients for rumen development. It might take as long as a year for the rumen to mature and for calves to establish a stable rumen microbiota system with many factors involved [104].

Both liquid and solid feed appear to affect the microbial community in young calves [107]. In this review, our discussion is restricted to the effect of forage feeding on the microbiota of young calves. Castells et al. [52] reported that forage supplementation (alfalfa) numerically increased cellulolytic microbes (Ruminococcus albus) compared with calves fed only concentrate feeds. Similarly, Kim et al. [54] observed significantly higher copy numbers of cellulolytic bacteria (Ruminococcus flavefaciens and Ruminococcus albus) in calves supplemented with forages (orchard and timothy hay). Early studies also evaluated the effects of the physical form (finely ground, $1 \mathrm{~mm}$ theoretical particle size vs. unground, $0.64 \mathrm{~cm}$ theoretical particle size) of diet on rumen microbiota with two identical diets (25\% alfalfa hay and $75 \%$ grain) that varied only in particle size. Calves offered the ground diet had a relatively lower rumen fluid $\mathrm{pH}$ and lower number of cellulolytic bacteria than calves fed the unground diet [89]. 
These results revealed that effective fiber might play a crucial role in changing the rumen environment, hence altering the microbial populations.

The next-generation sequencing (NGS) analysis has revealed that the major phyla in the rumen are Firmicutes (around 43\%), Bacteroidetes (around 21\%), Actinobacteria (around 18\%), and Proteobacteria (around 4\%) [108]. Relatively higher abundance of Bacteroidetes and lower abundance of Actinobacteria was observed in calves supplemented with forage compared to those fed only concentrate [54]. Bacteroidetes, the second most dominant phyla in calves' rumen, may stimulate the development of the digestive tract [109]. In adult cows fed concentrate feed, the relative abundance of Bacteroidetes dropped and cows were more susceptible to SARA [110]. The lower level of Bacteroidetes in calves fed only concentrate could be partly explained by greater feed intakes resulting in low rumen $\mathrm{pH}$. Furthermore, Kim et al. [54] found that the most dominant genus in Bacteroidetes phylum was Prevotella, a highly active hemicellulolytic and starch-degraders [111] that mainly produce acetate. A relatively higher abundance of Prevotella may be related to the greater acetate proportion in calves offered forage [54]. Jami et al. [104] reported that Prevotella was the predominant genus in animals fed high-fiber diets rather than high-caloric diets. Olsenella is an important lactic acid-producing bacterium under the phylum Actinobacteria [112]. Forage inclusion decreases Olsenella (hay, 3.9\% vs. concentrate, 13.2\%) significantly, which contributes to the lower abundance of Actinobacteria (hay, $4.7 \%$ vs. concentrate, 13.9\%) [54]. Thus, it can be speculated that forage inclusion in the diet might affect the growth of lactic acid-producing bacteria (such as Olsenella) by limiting the proportion of rapidly fermentable substrates (e.g., starch) replaced by fiber. In contrast, although numerical differences were observed in Bacteroidetes and Actinobacteria when evaluating the effect of forage supplementation, Lin et al. [108] reported that neither alpha nor beta diversity indices and microbiota were significantly different among the dietary groups [108], possibly because of the volume of milk (Lin, $252 \mathrm{~L}, 10 \%$ vs. Kim, $88 \mathrm{~L}, 4 \%$ of birth bodyweight) fed to calves, resulting in varying solid feed consumed. Alternatively, different forage sources (Lin, Oat hay vs. Kim, Timothy) and feeding levels (Forage/Total Solid: Lin, $6 \%$ vs. Kim, 20\%) (Tables 2 and 4 ) might have led to insufficient forage consumption causing the changes in the composition of rumen microbiota in the Lin et al. study. These results indicate that the population of most predominant microbiota (e.g., Bacteroidetes and Actinobacteria) in the rumen is closely related to the amount and type of solid feed consumed. Further studies need to focus on these major groups to illustrate the relationship between rumen microbiota, fermentation and feed consumption in dairy calves.

It is important to note that the effect of various nutritional (sugars, starch, rumen degradable protein, NDF, or ADF) and physical (effective forage fiber or non-forage fiber) fractions on rumen microorganisms in young calves is not clearly defined in literature. Furthermore, most of the studies evaluating microbial and molecular changes in young calves have only studied a small number of microbes of interest. With the rapid development of the NGS technologies in the past 20 years, we recommend the exploration of the global changes in microbial abundance to better understand substrate fermentation and absorption and epithelium development in the rumen as forage are supplemented to calves in early life.

\section{Feeding Behavior}

\subsection{Ruminating and Eating Behavior}

Feed experiences and behavior development in early life might affect the behavioral expression of adult ruminants [79]. In the last decade, researchers have increased their attention on the development of calf behaviors, such as eating, standing, lying, and ruminating when forage is included in the diet. Forage inclusion in the diet undoubtedly increases chewing in calves even before weaning when only a small amount of solid feed is consumed. Increased chewing activity may be as a result of higher rumination $[21,39,40,53,55,56,75-78]$ or the total time spent eating $[39,40,57,76,77]$ when calves are fed forage. 
In newborn ruminants, rumination is initially absent and emerge a few weeks after birth [113]. Providing forage to young calves can accelerate the development of rumination behavior $[114,115]$. van Ackeren et al. [116] observed that chewing time was lower in calves receiving a low NDF diet (26.2\%) compared with those receiving a high NDF diet (31.3\%). Porter et al. [37] claimed that calves began ruminating by week 4 of age when fed a more physically effective solid feed, while those fed a finely pelleted feed began ruminating from week 6 . Rumination is crucial in ruminants helping maintain the rumen fluid $\mathrm{pH}$ by stimulating saliva production that neutralize VFA and lactic acid in the rumen and thus to maintain a healthy rumen environment [105].

Meal feeding patterns (meal size, frequency, and duration) can also impact the rumen environment. Generally, rumen fluid $\mathrm{pH}$ declines rapidly after feed ingestion, and the rate of decrease is associated with meal size and feeding frequency [117]. Large meal sizes and infrequent meals may result in a greater drop in rumen fluid $\mathrm{pH}$ post-ingestion. Horvath et al. [57] illustrated that the provision of forage not only increased the total eating time but also influenced the solid feed meal patterns. An improved meal frequency and duration were observed in their study, which leads to relatively slower post-prandial drops in rumen fluid $\mathrm{pH}$, potentially decreasing the risk of SARA [63].

\subsection{Sorting Behavior}

Feed sorting is well demonstrated in adult cows, since they are highly sensitive to sweet taste [118]. Probably, the preference for sweetness reflects the inclination towards higher energy demands, hence the tendency to sort out for concentrates (sweet, high energy-density) in a total mixed ration [119]. The sorting out of the mixed ration can result in an unbalanced nutrient intake, whereby cows sort out for the rapidly fermentable cereals as opposed to forage, leading to a drop in rumen fluid $\mathrm{pH}$, and hence inducing SARA [120]. Ingesting excessive fermentable concentrate feed can result in rumen acidosis [63]. In turn, the sorting behavior is altered further, leading the animals to choose the part of diets with longer particle size and slower fermentable rate [121]. These results suggest that ruminants develop feed preferences based on post-ingestive feedback [122] and they may be biased towards choosing certain nutrients as the situation demands.

Feed sorting is also seen in the early life of calves. When feeding concentrates and forage free-choice, variation in the proportion of forage to total solid intake was observed (ranging from 5 and $45 \%)[21,25,87]$. The changes in dietary selection across multiple studies may depend on forage related factors and milk feeding allowance, as has been discussed above. It is interesting to note that feed preference and sorting can be established early and persist later on in life. Miller-Cushon et al. [123] reported that calves fed either concentrate or forage before weaning were likely to consume the feed that they were already familiar with, even when switched to a mixed diet after weaning. Similarly, our research group found that calves are likely to eat feed they were originally introduced to and familiar with even after switching to a free-choice diet, though this effect only lasted for a short period. However, after switching the diet at weaning, the provision of both concentrate and hay separately early in life led to a greater hay intake ratio $(35.6 \%)$ than providing concentrate $(17.7 \%)$ or hay $(16.5 \%)$ solely before weaning. Furthermore, exposure to a diet of both concentrate and hay early in life could numerically improve the calves' ability to sort for long particles 6 months later [25]. Therefore, these results suggest that early exposure to feed experience can affect the feed preference immediately after switching diets and may have a long-lasting effect. The feeding method may also play an essential role in influencing the learning of feed sorting behavior. When we compared three different feeding methods (solely concentrate, separated concentrate and forage, mixed concentrate and forage for the first month; data unpublished) in 2 month old calves, the lowest sorting activity was observed in calves fed concentrate and forage separately. Hence, calves exposed early to a diet of concentrate or mixed ration are likely to sort for fine-grain particles, probably because these calves have already established their sorting behavior, which can last even after changing to a new mixed diet (data unpublished). Similarly, the provision of solid feed in pre-weaned calves as separate components reduced the extent of feed sorting after weaning compared to offering the diet as a mixed ration [87]. As already stated, 
feed sorting is likely to influence rumen fluid $\mathrm{pH}$ and may lead to SARA. Separately feeding different solid feed components at the same time may avert sorting for fine particles when compared to feeding solely concentrate or mixed diets and might lead to a more stable rumen fluid $\mathrm{pH}$ and a healthier rumen in the calf. However, we cannot ignore the fact that the effect of forage inclusion on sorting behavior is dependent on a myriad of other factors (e.g., forage source, level, physical form, dry matter, and milk allowance).

\subsection{Other Behaviors}

Access to forage by dairy calves may also reduce the occurrence of other non-nutritive oral and abnormal behaviors $[21,40,53,55-57,76,85]$, such as tongue rolling, licking of buckets, pen or surface, sniffing, vocalizing, and eating the bedding material. Horvath et al. [85] demonstrated that providing forage decreased the non-nutritive oral behaviors, and when combined with feeding milk by teat, the effects were more significant compared with bucket feeding. These results further buttress the fact that liquid and solid feeding can influence the development of pre-weaned calf behaviors. Furthermore, supplementation of good quality forage increased other behaviors that may indicate satisfaction (tail swishing, self-grooming, and rubbing) [56]. Worthy to note is that the decline in non-nutritive oral behavior may have also reduced the formation of hair and fiber balls in the rumen [4], which have been associated with poor health and growth of calves. Further research is encouraged to explore whether forage inclusion early in life would have a long-term effect on sorting and other behaviors.

\section{Conclusions}

Understanding factors that influence responses to forage inclusion in pre-weaned calves is of significant importance from a management point of view because the effect of offering forage on calf feed intake and growth rate has been inconsistent. In recent studies, a small amount of good quality forage such as alfalfa supplemented in the diet is likely to improve the DMI and ADG. However, these performances are dependent on the type of concentrate and the amount of milk offered. Although controversy remains on whether forage improves growth rate, it has been well documented that its inclusion early in life can help with the establishment of feeding behavior, leading to greater rumination and eating behavior as well as lowering the abnormal feed sorting behavior. All these positive effects can result in a higher rumen fluid $\mathrm{pH}$ and a more stable rumen environment, with a corresponding positive effect on rumen microbiota and fermentation. Further research is required to understand the long-term effects of offering forage to pre-weaned calves, since animal-related factors, such as feed selection and sorting, established early in life may persist later on in life.

Author Contributions: The paper was mainly conceived and designed by Z.C. Research articles were collected and analyzed by J.X. and G.M.A. The manuscript was mainly written by J.X. and G.M.A. and edited by J.L., Y.W., S.L., and Z.C. All authors have read and agreed to the published version of the manuscript.

Funding: This research received no external funding.

Conflicts of Interest: The authors declare no conflict of interest.

\section{References}

1. Davenport, E. On the importance of the physiological requirements of the animal body; results of an attempt to grow cattle without coarse feed. III Agric. Exp. Sta. Bul. 1897, 46, 362.

2. Kertz, A.F.; Hill, T.M.; Heinrichs, A.J.; Linn, J.G.; Drackley, J.K. A 100-Year Review: Calf nutrition and management. J. Dairy Sci. 2017, 100, 10151. [CrossRef] [PubMed]

3. Mccandlish, A.C. Studies in the Growth and Nutrition of Dairy Calves: VI. The Addition of Hay and Grain to a Milk Ration for Calves. J. Dairy Sci. 1923, 6, 500-508. [CrossRef]

4. Pounden, W.D.; Hibbs, J.W.; Cole, C.R. Observations on the relation of diet to diarrhea in young dairy calves. J. Am. Vet. Med. Assoc. 1951, 118, 400. 
5. Hibbs, J.W.; Conrad, H.R.; Pounden, W.D.; Frank, N. A High Roughage System for Raising Calves Based on Early Development of Rumen Function. VI. Influence of Hay to Grain Ratio on Calf Performance, Rumen Development, and Certain Blood Changes. J. Dairy Sci. 1956, 39, 171-179. [CrossRef]

6. Hibbs, J.W.; Pounden, W.D.; Conrad, H.R. A high roughage system for raising calves based on the early development of rumen function. 1. Effect of variations in the ration on growth, feed consumption, and utilization. J. Dairy Sci. 1953, 36, 717-727. [CrossRef]

7. Warner, R.G.; Flatt, W.P.; Loosli, J.K. Dietary factors influencing the development of the ruminant stomach. J. Agric. Food Chem. 1956, 4, 788-792. [CrossRef]

8. Suarez-Mena, F.X.; Hill, T.M.; Jones, C.M.; Heinrichs, A.J. Review: Effect of forage provision on feed intake in dairy calves. Prof. Anim. Sci. 2016, 32, 383-388. [CrossRef]

9. Davis, C.L.; Drackley, J.K. The Development, Nutrition, and Management of the Young Calf; Iowa State University Press: Ames, IA, USA, 1998.

10. Sander, E.G.; Warner, R.G.; Harrison, H.N.; Loosli, J.K. The Stimulatory Effect of Sodium Butyrate and Sodium Propionate on the Development of Rumen Mucosa in the Young Calf. J. Dairy Sci. 1959, 42, 1600-1605. [CrossRef]

11. Tamate, H.; Mcgilliard, A.D.; Jacobson, N.L.; Getty, R. Effect of Various Dietaries on the Anatomical Development of the Stomach in the Calf 1. J. Dairy Sci. 1962, 45, 408-420. [CrossRef]

12. Carroll, E.; Hungate, R. The magnitude of the microbial fermentation in the bovine rumen. Appl. Microbiol. 1954, 2, 205. [CrossRef] [PubMed]

13. Stobo, I.J.F.; Roy, J.H.B.; Gaston, H.J. Rumen development in the calf: 2.* The effect of diets containing different proportions of concentrates to hay on digestive efficiency. Br. J. Nutr. 1966, 20, 189. [CrossRef] [PubMed]

14. Leibholz, J. Ground roughage in the diet of the early-weaned calf. Anim. Prod. 1975, 20, 93-100. [CrossRef]

15. Hill, T.M.; Ii, H.G.B.; Aldrich, J.M.; Schlotterbeck, R.L. Effects of the Amount of Chopped Hay or Cottonseed Hulls in a Textured Calf Starter on Young Calf Performance. J. Dairy Sci. 2008, 91, 2684-2693. [CrossRef]

16. National Academies Press. Nutrient Requirements of Dairy Cattle; National Academies Press: Washington, WA, USA, 2001.

17. Hill, T.M.; Ii, H.G.B.; Pas, J.M.A.; Schlotterbeck, R.L. Roughage for Diets Fed to Weaned Dairy Calves. Prof. Anim. Sci. 2009, 25, 283-288. [CrossRef]

18. Castells, L.; Bach, A.; Terré, M. Short- and long-term effects of forage supplementation of calves during the preweaning period on performance, reproduction, and milk yield at first lactation. J. Dairy Sci. 2015, 98, 4748-4753. [CrossRef]

19. Coverdale, J.A.; Tyler, H.D.; Brumm, J.A. Effect of various levels of forage and form of diet on rumen development and growth in calves. J. Dairy Sci. 2004, 87, 2554-2562. [CrossRef]

20. Khan, M.A.; Weary, D.M.; Keyserlingk, M.A.G.V. Hay intake improves performance and rumen development of calves fed higher quantities of milk. J. Dairy Sci. 2011, 94, 3547-3553. [CrossRef]

21. Castells, L.; Bach, A.; Araujo, G.; Montoro, C.; Terré, M. Effect of different forage sources on performance and feeding behavior of Holstein calves. J. Dairy Sci. 2012, 95, 286-293. [CrossRef]

22. Beiranvand, H.; Ghorbani, G.R.; Khorvash, M.; Nabipour, A.; Dehghanbanadaky, M.; Homayouni, A.; Kargar, S. Interactions of alfalfa hay and sodium propionate on dairy calf performance and rumen development. J. Dairy Sci. 2014, 97, 2270-2280. [CrossRef]

23. Daneshvar, D.; Khorvash, M.; Ghasemi, E.; Mahdavi, A.H.; Moshiri, B.; Mirzaei, M.; Pezeshki, A.; Ghaffari, M.H. The effect of restricted milk feeding through conventional or step-down methods with or without forage provision in starter feed on performance of Holstein bull calves. J. Anim. Sci. 2015, 93, 3979-3989. [CrossRef] [PubMed]

24. Wu, Z.; Azarfar, A.; Simayi, A.; Li, S.; Jonker, A.; Cao, Z. Effects of forage type and age at which forage provision is started on growth performance, rumen fermentation, blood metabolites and intestinal enzymes in Holstein calves. Anim. Prod. Sci. 2018, 58, 2288-2299. [CrossRef]

25. Xiao, J.; Guo, L.; Alugongo, G.; Wang, Y.; Cao, Z.; Li, S. Effects of different feed type exposure in early life on performance, rumen fermentation, and feed preference of dairy calves. J. Dairy Sci. 2018, 101, 8169-8181. [CrossRef] [PubMed] 
26. Jahanimoghadam, M.; Mahjoubi, E.; Yazdi, M.H.; Cardoso, F.C.; Drackley, J.K. Effects of alfalfa hay and its physical form (chopped versus pelleted) on performance of Holstein calves. J. Dairy Sci. 2015, 98, 4055-4061. [CrossRef]

27. Mirzaei, M.; Khorvash, M.; Ghorbani, G.R.; Kazemi-Bonchenari, M.; Riasi, A.; Nabipour, A.; Borne, J.J.G.C. Effects of supplementation level and particle size of alfalfa hay on growth characteristics and rumen development in dairy calves. J. Anim. Physiol. Anim. Nutr. 2015, 99, 553-564. [CrossRef]

28. Gelsinger, S.L.; Heinrichs, A.J.; Jones, C.M. A meta-analysis of the effects of preweaned calf nutrition and growth on first-lactation performance1. J. Dairy Sci. 2016, 99, 6206-6214. [CrossRef]

29. Kilgour, R.J. In pursuit of "normal": A review of the behaviour of cattle at pasture. Appl. Anim. Behav. Sci. 2012, 138, 1-11. [CrossRef]

30. Nicol, A.M.; Sharafeldin, M.A. Observations on the behaviour of single-suckled calves from birth to 120 days. Proc NZ Soc. Anim. Prod. 1975.

31. Tedeschi, L.O.; Fox, D.G. Predicting milk and forage intake of nursing calves. J. Anim. Sci. 2009, 87, 3380-3391. [CrossRef]

32. Miller-Cushon, E. Expression and Development of Feeding Behaviour in Dairy Calves. Ph.D. Thesis, University of Guelph, Guelph, ON, Canada, 6 May 2014.

33. Drackley, J.K. Calf Nutrition from Birth to Breeding. Vet. Clin. North Am. Food Anim. Pract. 2008, $24,55-86$. [CrossRef]

34. Imani, M.; Mirzaei, M.; Baghbanzadehnobari, B.; Ghaffari, M.H. Effects of forage provision to dairy calves on growth performance and rumen fermentation: A meta-analysis and meta-regression. J. Dairy Sci. 2017, 100, 1136-1150. [CrossRef] [PubMed]

35. Conrad, H.R.; Hibbs, J.W. A High Roughage System for Raising Calves Based on the Early Development of Rumen Function. VII. Utilization of Grass Silage, Pasture, and Pelleted Alfalfa Meal. J. Dairy Sci. 1956, 39, 1170-1179. [CrossRef]

36. Stobo, I.J.F.; Roy, J.H.B.; Gaston, H.J. Rumen development in the calf. 1. The effect of diets containing different proportions of concentrates to hay on rumen development. Br. J. Nutr. 1966, 20, 171-188. [CrossRef]

37. Porter, J.C.; Warner, R.G.; Pas, A.F.K. Effect of Fiber Level and Physical Form of Starter on Growth and Development of Dairy Calves Fed No Forage. Prof. Anim. Sci. 2007, 23, 395-400. [CrossRef]

38. Nemati, M.; Amanlou, H.; Khorvash, M.; Mirzaei, M.; Moshiri, B.; Ghaffari, M.H. Effect of different alfalfa hay levels on growth performance, rumen fermentation, and structural growth of Holstein dairy calves. J. Anim. Sci. 2016, 94, 1141. [CrossRef] [PubMed]

39. Maktabi, H.; Ghasemi, E.; Khorvash, M. Effects of substituting grain with forage or nonforage fiber source on growth performance, rumen fermentation, and chewing activity of dairy calves. Anim. Feed Sci. Technol. 2016, 221, 70-78. [CrossRef]

40. Hosseini, S.; Mirzaei-Alamouti, H.; Vazirigohar, M.; Mahjoubi, E.; Rezamand, P. Effects of whole milk feeding rate and straw level of starter feed on performance, rumen fermentation, blood metabolites, structural growth, and feeding behavior of Holstein calves. Anim. Feed Sci. Technol. 2019, 255, 114238. [CrossRef]

41. Jahn, E.; Chandler, P.T.; Polan, C.E. Effects of fiber and ratio of starch to sugar on performance of ruminating calves. J. Dairy Sci. 1970, 53, 466-474. [CrossRef]

42. Zitnan, R.; Voigt, J.; Schönhusen, U.; Wegner, J.; Kokardová, M.; Hagemeister, H.; Levkut, M.; Kuhla, S.; Sommer, A. Influence of dietary concentrate to forage ratio on the development of rumen mucosa in calves. Arch. Anim. Nutr. 1998, 51, 279-291.

43. Suárez, B.; Van Reenen, C.; Stockhofe, N.; Dijkstra, J.; Gerrits, W. Effect of roughage source and roughage to concentrate ratio on animal performance and rumen development in veal calves. J. Dairy Sci. 2007, 90, 2390-2403. [CrossRef]

44. Kehoe, S.I.; Dill-McFarland, K.A.; Breaker, J.D.; Suen, G. Effects of corn silage inclusion in preweaning calf diets. J. Dairy Sci. 2019, 102, 4131-4137. [CrossRef] [PubMed]

45. ASAE. Method of Determining and Expressing Particle Size of Chopped Forage Material by Screening; ASAE: St. Joseph, MI, USA, 1998.

46. Booth, J.A. Effect of Forage Addition to the Diet on Rumen Development in Calves; Retrospective Theses and Dissertations; Iowa State University: Ames, IA, USA, 2003; p. 564.

47. ÜLGER, İ.; Kaliber, M.; BEYZİ, S.B.; Konca, Y. Effects of Different Quality Roughage Supply on Performance of Holstein Calves during Preweaning Period. Tarim Bilimleri Dergisi J. Agric. Sci. 2017, 23, 386-394. 
48. Hill, T.; Dennis, T.; Suárez-Mena, F.; Quigley, J.; Aragona, K.; Schlotterbeck, R. Effects of free-choice hay and straw bedding on digestion of nutrients in 7-week-old Holstein calves. Appl. Anim. Sci. 2019, 35, 312-317. [CrossRef]

49. Hill, T.; Suárez-Mena, F.; Dennis, T.; Quigley, J.; Schlotterbeck, R. Effects of free-choice hay on intake and growth of Holstein calves fed a textured starter to 2 months of age. Appl. Anim. Sci. 2019, 35, 161-168. [CrossRef]

50. Anderson, M.J.; Khoyloo, M.; Walters, J.L. Effect of Feeding Whole Cottonseed on Intake, Body Weight, and Reticulorumen Development of Young Holstein Calves. J. Dairy Sci. 1982, 65, 764-772. [CrossRef]

51. Suárez, B.J.; Van Reenen, C.G.; Beldman, G.; Van, D.J.; Dijkstra, J.; Gerrits, W.J. Effects of supplementing concentrates differing in carbohydrate composition in veal calf diets: I. Animal performance and rumen fermentation characteristics. J. Dairy Sci. 2006, 89, 4365-4375. [CrossRef]

52. Castells, L.; Bach, A.; Aris, A.; Terré, M. Effects of forage provision to young calves on rumen fermentation and development of the gastrointestinal tract. J. Dairy Sci. 2013, 96, 5226-5236. [CrossRef]

53. Terré, M.; Pedrals, E.; Dalmau, A.; Bach, A. What do preweaned and weaned calves need in the diet: A high fiber content or a forage source? J. Dairy Sci. 2013, 96, 5217-5225. [CrossRef]

54. Kim, Y.-H.; Nagata, R.; Ohtani, N.; Ichijo, T.; Ikuta, K.; Sato, S. Effects of dietary forage and calf starter diet on ruminal $\mathrm{pH}$ and bacteria in Holstein calves during weaning transition. Front. Microbiol. 2016, 7, 1575. [CrossRef]

55. Mirzaei, M.; Khorvash, M.; Ghorbani, G.R.; Kazemi-Bonchenari, M.; Ghaffari, M.H. Growth performance, feeding behavior, and selected blood metabolites of Holstein dairy calves fed restricted amounts of milk: No interactions between sources of finely ground grain and forage provision. J. Dairy Sci. 2017, 100, 1086-1094. [CrossRef]

56. Phillips, C.J. The effects of forage provision and group size on the behavior of calves. J. Dairy Sci. 2004, 87, 1380-1388. [CrossRef]

57. Horvath, K.; Miller-Cushon, E. Evaluating effects of providing hay on behavioral development and performance of group-housed dairy calves. J. Dairy Sci. 2019, 102, 10411-10422. [CrossRef] [PubMed]

58. Kargar, S.; Kanani, M.; Albenzio, M.; Caroprese, M. Substituting corn silage with reconstituted forage or nonforage fiber sources in the starter diets of Holstein calves: Effects on performance, ruminal fermentation, and blood metabolites. J. Anim. Sci. 2019, 97, 3046-3055. [CrossRef]

59. Kargar, S.; Kanani, M. Substituting corn silage with reconstituted forage or nonforage fiber sources in the starter feed diets of Holstein calves: Effects on intake, meal pattern, sorting, and health. J. Dairy Sci. 2019, 102, 7168-7178. [CrossRef]

60. Owens, F.N.; Secrist, D.S.; Hill, W.J.; Gill, D.R. Acidosis in cattle: A review. J. Anim. Sci. 1998, 76, $275-286$. [CrossRef] [PubMed]

61. Kononoff, P.; Heinrichs, A.J. The effect of reducing alfalfa haylage particle size on cows in early lactation. J. Dairy Sci. 2003, 86, 1445-1457. [CrossRef]

62. Montoro, C.; Miller-Cushon, E.; DeVries, T.; Bach, A. Effect of physical form of forage on performance, feeding behavior, and digestibility of Holstein calves. J. Dairy Sci. 2013, 96, 1117-1124. [CrossRef]

63. Krause, K.M.; Oetzel, G.R. Understanding and preventing subacute ruminal acidosis in dairy herds: A review. Anim. Feed Sci. Technol. 2006, 126, 215-236. [CrossRef]

64. Laarman, A.; Oba, M. Effect of calf starter on rumen $\mathrm{pH}$ of Holstein dairy calves at weaning. J. Dairy Sci. 2011, 94, 5661-5664. [CrossRef]

65. Omidi-Mirzaei, H.; Azarfar, A.; Mirzaei, M.; Kiani, A.; Ghaffari, M. Effects of forage source and forage particle size as a free-choice provision on growth performance, rumen fermentation, and behavior of dairy calves fed texturized starters. J. Dairy Sci. 2018, 101, 4143-4157. [CrossRef]

66. Suárez-Mena, F.X.; Heinrichs, A.J.; Jones, C.M.; Hill, T.M.; Quigley, J.D. Straw particle size in calf starters: Effects on digestive system development and rumen fermentation. J. Dairy Sci. 2015, 99, 341-353. [CrossRef] [PubMed]

67. Mirzaei, M.; Khorvash, M.; Ghorbani, G.R.; Kazemi-Bonchenari, M.; Riasi, A.; Soltani, A.; Moshiri, B.; Ghaffari, M.H. Interactions between the physical form of starter (mashed versus textured) and corn silage provision on performance, rumen fermentation, and structural growth of Holstein calves. J. Anim. Sci. 2016, 94, 678-686. [CrossRef] [PubMed] 
68. Beiranvand, H.; Khani, M.; Omidian, S.; Ariana, M.; Rezvani, R.; Ghaffari, M. Does adding water to dry calf starter improve performance during summer? J. Dairy Sci. 2016, 99, 1903-1911. [CrossRef] [PubMed]

69. Beiranvand, H.; Khani, M.; Ahmadi, F.; Omidi-Mirzaei, H.; Ariana, M.; Bayat, A. Does adding water to a dry starter diet improve calf performance during winter? Animal 2019, 13, 959-967. [CrossRef] [PubMed]

70. Kargar, S.; Kanani, M. Reconstituted versus dry alfalfa hay in starter feed diets of Holstein dairy calves: Effects on feed intake, feeding and chewing behavior, feed preference, and health criteria. J. Dairy Sci. 2019, 102, 4061-4071. [CrossRef]

71. Kargar, S.; Kanani, M. Reconstituted versus dry alfalfa hay in starter feed diets of Holstein dairy calves: Effects on growth performance, nutrient digestibility, and metabolic indications of rumen development. J. Dairy Sci. 2019, 102, 4051-4060. [CrossRef]

72. Van Soest, P.J. Nutritional Ecology of the Ruminant; Cornell university press: Ithaca, NY, USA, 1994; Volume 44, pp. 2552-2561.

73. Pasha, T.N.; Prigge, E.C.; Russell, R.W.; Bryan, W.B. Influence of moisture content of forage diets on intake and digestion by sheep. J. Anim. Sci. 1994, 72, 2455-2463. [CrossRef]

74. Dill-McFarland, K.A.; Weimer, P.J.; Breaker, J.D.; Suen, G. Diet influences early microbiota development in dairy calves without long-term impacts on milk production. Appl. Environ. Microbiol. 2019, 85, e02141-18. [CrossRef]

75. Hosseini, S.M.; Ghorbani, G.R.; Khorvash, P.R.M. Determining optimum age of Holstein dairy calves when adding chopped alfalfa hay to meal starter diets based on measures of growth and performance. Anim. Int. J. Anim. Biosci. 2015, 10, 607. [CrossRef]

76. Lin, X.; Wang, Y.; Wang, J.; Hou, Q.; Hu, Z.; Shi, K.; Yan, Z.; Wang, Z. Effect of initial time of forage supply on growth and rumen development in preweaning calves. Anim. Prod. Sci. 2018, 58, 2224-2232. [CrossRef]

77. Overvest, M.A.; Bergeron, R.; Haley, D.B.; Devries, T.J. Effect of feed type and method of presentation on feeding behavior, intake, and growth of dairy calves fed a high level of milk. J. Dairy Sci. 2015, 99, 317-327. [CrossRef] [PubMed]

78. Ebnali, A.; Khorvash, M.; Ghorbani, G.R.; Mahdavi, A.H.; Malekkhahi, M.; Mirzaei, M.; Pezeshki, A.; Ghaffari, M.H. Effects of forage offering method on performance, rumen fermentation, nutrient digestibility and nutritional behaviour in Holstein dairy calves. J. Anim. Physiol. A Anim. Nutr. 2016, 100, 820-827. [CrossRef] [PubMed]

79. Miller-Cushon, E.K.; DeVries, T.J. Feed sorting in dairy cattle: Causes, consequences, and management. J. Dairy Sci. 2017, 100, 4172-4183. [CrossRef] [PubMed]

80. Terrã, M.; Castells, L.; Khan, M.A.; Bach, A. Interaction between the physical form of the starter feed and straw provision on growth performance of Holstein calves. J. Dairy Sci. 2015, 98, 1101-1109. [CrossRef]

81. Lesmeister, K.; Heinrichs, A.J. Effects of corn processing on growth characteristics, rumen development, and rumen parameters in neonatal dairy calves. J. Dairy Sci. 2004, 87, 3439-3450. [CrossRef]

82. Mojahedi, S.; Khorvash, M.; Ghorbani, G.R.; Ghasemi, E.; Mirzaei, M.; Hashemzadeh-Cigari, F. Performance, nutritional behavior, and metabolic responses of calves supplemented with forage depend on starch fermentability. J. Dairy Sci. 2018, 101, 7061-7072. [CrossRef]

83. Bateman Ii, H.; Hill, T.; Aldrich, J.; Schlotterbeck, R. Effects of corn processing, particle size, and diet form on performance of calves in bedded pens. J. Dairy Sci. 2009, 92, 782-789. [CrossRef]

84. Kosiorowska, A.; Puggaard, L.; Hedemann, M.S.; Sehested, J.; Jensen, S.K.; Kristensen, N.B.; Kuropka, P.; Marycz, K.; Vestergaard, M. Gastrointestinal development of dairy calves fed low- or high-starch concentrate at two milk allowances. Animal 2011, 5, 211-219. [CrossRef]

85. Horvath, K.; Miller-Cushon, E. The effect of milk-feeding method and hay provision on the development of feeding behavior and non-nutritive oral behavior of dairy calves. J. Dairy Sci. 2017, 100, 3949-3957. [CrossRef]

86. Thomas, D.B.; Hinks, C.E. The effect of changing the physical form of roughage on the performance of the early-weaned calf. Anim. Sci. 1982, 35, 375-384. [CrossRef]

87. Millercushon, E.K.; Bergeron, R.; Leslie, K.E.; Mason, G.J.; Devries, T.J. Effect of early exposure to different feed presentations on feed sorting of dairy calves. J. Dairy Sci. 2013, 96, 4624-4633. [CrossRef] [PubMed]

88. Khan, M.A.; Lee, H.J.; Lee, W.S. Structural growth, rumen development, and metabolic and immune responses of Holstein male calves fed milk through step-down and conventional methods. J. Dairy Sci. 2007, 90, 3376-3387. [CrossRef] [PubMed] 
89. Beharka, A.A.; Nagaraja, T.G.; Morrill, J.L.; Kennedy, G.A.; Klemm, R.D. Effects of form of the diet on anatomical, microbial, and fermentative development of the rumen of neonatal calves. J. Dairy Sci. 1998, 81, 1946. [CrossRef]

90. Schwartzkopf-Genswein, K.S.; Beauchemin, K.A.; Gibb, D.J.; Crews, D.H.; Mcallister, T.A. Effect of bunk management on feeding behavior, ruminal acidosis and performance of feedlot cattle: A review. J. Anim. Sci. 2003, 81, E149-E158.

91. Garrett, E.F.; Pereira, M.N.; Nordlund, K.V. Diagnostic Methods for the Detection of Subacute Ruminal Acidosis in Dairy Cows. J. Dairy Sci. 1999, 82, 1170-1178. [CrossRef]

92. Quigley, J.D.; Steen, T.M.; Boehms, S.I. Postprandial Changes of Selected Blood and Ruminal Metabolites in Ruminating Calves Fed Diets with or Without Hay. J. Dairy Sci. 1992, 75, 228-235. [CrossRef]

93. Kay, R.N.B. The rate of flow and composition of various salivary secretions in sheep and calves. J. Physiol. 1960, 150, 515-537. [CrossRef]

94. Laarman, A.H.; Ruiz-Sanchez, A.L.; Sugino, T.; Guan, L.L.; Oba, M. Effects of feeding a calf starter on molecular adaptations in the ruminal epithelium and liver of Holstein dairy calves. J. Dairy Sci. 2012, 95, 2585-2594. [CrossRef]

95. Hodgson, J. The development of solid food intake in calves. 1. The effect of previous experience of solid food, and the physical form of the diet, on the development of food intake after weaning. Anim. Sci. 1971, 13, 15-24. [CrossRef]

96. Baldwin, R.L.V.; Mcleod, K.R.; Klotz, J.L.; Heitmann, R.N. Rumen development, intestinal growth and hepatic metabolism in the pre- and postweaning ruminant. J. Dairy Sci. 2004, 87, E55-E65. [CrossRef]

97. Kirat, D.; Masuoka, J.; Hayashi, H.; Iwano, H.; Yokota, H.; Taniyama, H.; Kato, S. Monocarboxylate transporter 1 (MCT1) plays a direct role in short-chain fatty acids absorption in caprine rumen. J. Physiol. 2006, 576, 635-647. [CrossRef] [PubMed]

98. Graham, C.; Gatherar, I.; Haslam, I.; Glanville, M.; Simmons, N.L. Expression and localization of monocarboxylate transporters and sodium/proton exchangers in bovine rumen epithelium. AJP Regul. Integr. Comp. Physiol. 2007, 292, R997-R1007. [CrossRef] [PubMed]

99. Flatt, W.P.; Warner, R.G.; Loosli, J.K. Influence of Purified Materials on the Development of the Ruminant Stomach. J. Dairy Sci. 1958, 41, 1593-1600. [CrossRef]

100. Cline, J.H.; Hershberger, T.V.; Bentley, O.G. Utilization and/or Synthesis of Valeric Acid during the Digestion of Glucose, Starch and Cellulose by Rumen Micro-Organisms. J. Anim. Sci. 1958, 17, 284-292. [CrossRef]

101. Briggs, P.; Hogan, J.; Reid, R. Effect of volatile fatty acids, lactic acid and ammonia on rumen $\mathrm{pH}$ in sheep. Aust. J. Agric. Res. 1957, 8, 674. [CrossRef]

102. Oetzel, G.R.; Nordlund, K.V.; Garrett, E.F. Effect of ruminal pH and stage of lactation on ruminal lactate concentration in dairy cows. J. Dairy Sci. 1999, 82, 38.

103. Kennelly, J.J.; Robinson, B.; Khorasani, G.R. Influence of carbohydrate source and buffer on rumen fermentation characteristics, milk yield, and milk composition in early-lactation Holstein cows. J. Dairy Sci. 1999, 82, 2486-2496. [CrossRef]

104. Jami, E.; Israel, A.; Kotser, A.; Mizrahi, I. Exploring the bovine rumen bacterial community from birth to adulthood. ISME J. 2013, 7, 1069-1079. [CrossRef]

105. Khan, M.A.; Bach, A.; Weary, D.M.; von Keyserlingk, M.A.G. Invited review: Transitioning from milk to solid feed in dairy heifers. J. Dairy Sci. 2016, 99, 885-902. [CrossRef]

106. Guzman, C.E.; Bereza-Malcolm, L.T.; De Groef, B.; Franks, A.E. Presence of Selected Methanogens, Fibrolytic Bacteria, and Proteobacteria in the Gastrointestinal Tract of Neonatal Dairy Calves from Birth to 72 Hours. PLoS ONE 2015, 10, e0133048. [CrossRef] [PubMed]

107. Rey, M.; Enjalbert, F.; Combes, S.; Cauquil, L.; Bouchez, O.; Monteils, V. Establishment of ruminal bacterial community in dairy calves from birth to weaning is sequential. J. Appl. Microbiol. 2014, 116, 245-257. [CrossRef] [PubMed]

108. Lin, X.; Wang, j.; Hou, Q.; Wang, Y.; Hu, Z.; Shi, K.; Yan, Z.; Wang, Z. Effect of hay supplementation timing on rumen microbiota in suckling calves. MicrobiologyOpen 2018, 7, e00430. [CrossRef] [PubMed]

109. Thomas, F.; Hehemann, J.H.; Rebuffet, E.; Czjzek, M.; Michel, G. Environmental and gut bacteroidetes: The food connection. Front. Microbiol. 2011, 2, 93. [CrossRef] [PubMed]

110. Sato, S. Pathophysiological evaluation of subacute ruminal acidosis (SARA) by continuous ruminal $\mathrm{pH}$ monitoring. Anim. Sci. J. 2016, 87, 168-177. [CrossRef] 
111. Matsui, H.; Ogata, K.; Tajima, K.; Nakamura, M.; Nagamine, T.; Aminov, R.I.; Benno, Y. Phenotypic Characterization of Polysaccharidases Produced by FourPrevotellaType Strains. Curr. Microbiol. 2000, 41, 45-49. [CrossRef]

112. Hobson, P.N.; Stewart, C.S. The Rumen Microbial Ecosystem; Springer Science \& Business Media: Berlin/Heidelberg, Germany, 2012.

113. Morisse, J.P.; Huonnic, D.; Cotte, J.P.; Martrenchar, A. The effect of four fibrous feed supplementations on different welfare traits in veal calves. Anim. Feed Sci. Technol. 2000, 84, 129-136. [CrossRef]

114. Costa, J.H.C.; Daros, R.R.; von Keyserlingk, M.A.G.; Weary, D.M. Complex social housing reduces food neophobia in dairy calves. J. Dairy Sci. 2014, 97, 7804-7810. [CrossRef]

115. Khan, M.A.; Weary, D.M.; Veira, D.M.; Von Keyserlingk, M.A.G. Postweaning performance of heifers provided hay during the milk feeding period. J. Dairy Sci. 2012, 95, 3970-3976. [CrossRef]

116. Van Ackeren, C.; Steingaß, H.; Hartung, K.; Funk, R.; Drochner, W. Effect of roughage level in a total mixed ration on feed intake, ruminal fermentation patterns and chewing activity of early-weaned calves with ad libitum access to grass hay. Anim. Feed Sci. Technol. 2009, 153, 48-59. [CrossRef]

117. Allen, M.S. Relationship Between Fermentation Acid Production in the Rumen and the Requirement for Physically Effective Fiber. J. Dairy Sci. 1997, 80, 1447-1451. [CrossRef]

118. Ginane, C.; Baumont, R.; Favreaupeigné, A. Perception and hedonic value of basic tastes in domestic ruminants. Physiol. Behav. 2011, 104, 666-674. [CrossRef]

119. Leonardi, C.; Armentano, L.E. Effect of quantity, quality, and length of alfalfa hay on selective consumption by dairy cows. J. Dairy Sci. 2003, 86, 557-564. [CrossRef]

120. Gao, X.; Oba, M. Relationship of severity of subacute ruminal acidosis to rumen fermentation, chewing activities, sorting behavior, and milk production in lactating dairy cows fed a high-grain diet. J. Dairy Sci. 2014, 97, 3006-3016. [CrossRef] [PubMed]

121. Maulfair, D.D.; McIntyre, K.K.; Heinrichs, A.J. Subacute ruminal acidosis and total mixed ration preference in lactating dairy cows. J. Dairy Sci. 2013, 96, 6610-6620. [CrossRef] [PubMed]

122. Burritt, E.A.; Provenza, F.D. Lambs form preferences for nonnutritive flavors paired with glucose. J. Anim. Sci. 1992, 70, 1133. [CrossRef] [PubMed]

123. Miller-Cushon, E.K.; Devries, T.J. Effect of early feed type exposure on diet-selection behavior of dairy calves. J. Dairy Sci. 2011, 94, 342. [CrossRef] 